\title{
A Comparison of Geospatially Modeled Fire Behavior and Potential Application to Fire and Fuels Management for the Savannah River Site
}

December 20, 2011

\author{
Laurie Kurth ${ }^{1}$, LaWen Hollingsworth ${ }^{2}$, Dan Shea ${ }^{3}$ \\ ${ }^{1}$ USDA Forest Service, Wildland Fire Management RD\&A \\ ${ }^{2}$ USDA Forest Service, Rocky Mountain Research Station, Fire Modeling Institute \\ ${ }^{3}$ USDA Forest Service-Region 8 Fire and Aviation Management
}




\section{Abstract}

Landscape-scale fire behavior analyses are important to inform decisions on resource management projects to meet land management objectives and protect values from adverse consequences of fire. Deterministic and probabilistic geospatial fire behavior analyses are conducted with various modeling systems including FARSITE, FlamMap, FSPro (Fire Spread Probability), and the Large Fire Simulation System (FSim). The fundamental fire spread algorithms in these systems require surface fire behavior fuel models and canopy cover to model surface fire behavior. Canopy base height, stand height, and canopy bulk density are required in addition to surface fire behavior fuel models and canopy cover to model crown fire activity. Several surface fuel and canopy classification efforts have used various remote sensing and ecological relationships as core methods to develop the spatial layers. All of these methods depend upon consistent and temporally constant interpretations of crown attributes and their ecological conditions to estimate surface fuel conditions.

This study evaluates modeled fire behavior for the Savannah River Site in the Atlantic Coastal Plain of the southeastern U.S. using three data sources: FCCS, LANDFIRE, and SWRA. The Fuel Characteristic Classification System (FCCS) was used to build fuelbeds from intensive field sampling of 629 plots. Custom fire behavior fuel models were derived from these fuelbeds. LANDFIRE developed surface fire behavior fuel models and canopy attributes for the U.S. using satellite imagery informed by field data. The Southern Wildfire Risk Assessment (SWRA) developed surface fire behavior fuel models and canopy cover for the southeastern U.S. using satellite imagery.

Differences in modeled fire behavior, data development, and data utility are summarized to assist in determining which data source may be most applicable for various land management activities and required analyses. Characterizing fire behavior under different fuel relationships provides insights for natural ecological processes, management strategies for fire mitigation, and positive and negative features of different fire behavior systems. A comparison of flame length, rate of spread, crown fire activity, and burn probabilities modeled with FlamMap shows some similar patterns across the landscape from all data sources, but there are potentially important differences. All data sources showed an expected range of fire behavior with rate of spread varying greatest. In all cases, crown fire activity was minimal. 


\section{Contents}

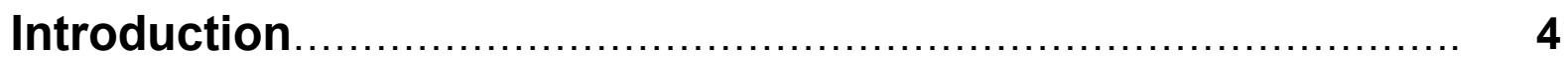

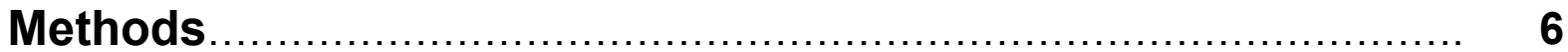

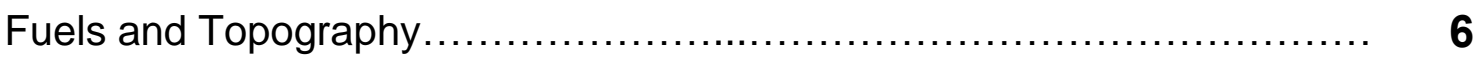

Weather and Fuel Moisture............................................... 8

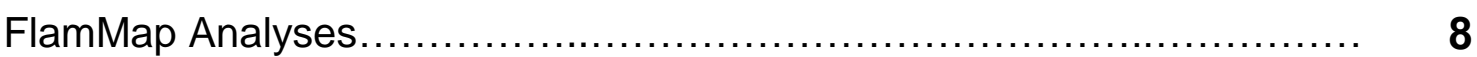

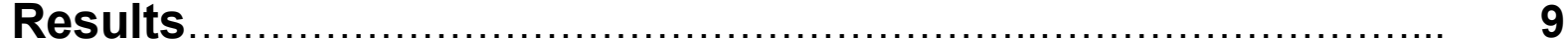

Landscape Results.........................................................

Surface Fire Behavior Fuel Models Results.............................. 19

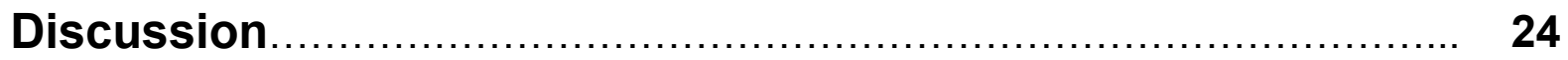

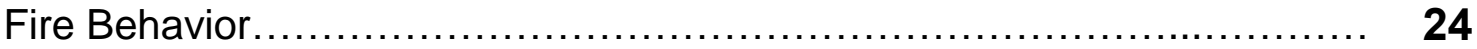

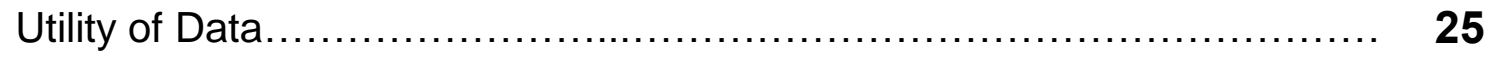

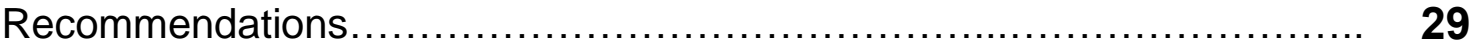

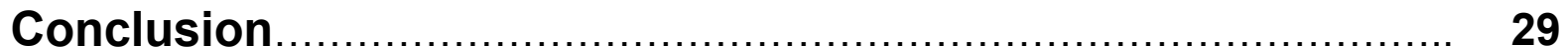

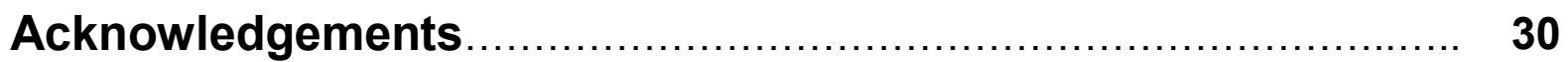

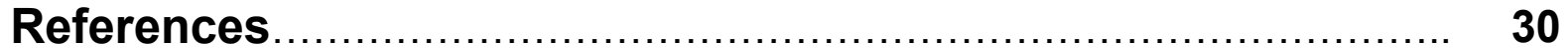

\section{Appendices}

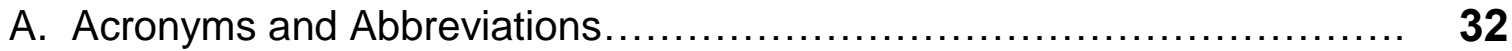

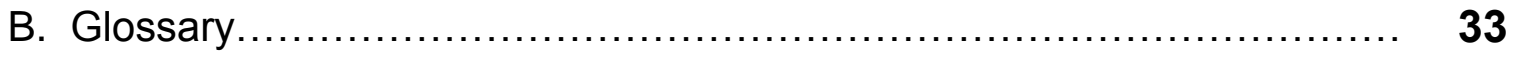

C. FlamMap Theme by Data Source ..................................... 34

D. Limitations, Assumptions, and Scientific Accuracy ...................... 35

E. Data Products Provided............................................... 37 


\section{Introduction}

The Savannah River Site (SRS) covers an area of approximately 198,350 acres in west-central South Carolina along the Savannah River. The SRS is owned by the Department of Energy (DOE) and is part of the nation's nuclear complex. Working under an interagency agreement with the DOE the USDA Forest Service-Savannah River (USFS-SR) is responsible for management of the natural resources at SRS. This includes all aspects of fire suppression and fuels management. The area is part of the Southern Atlantic Coastal Plain and dominant vegetation types include loblolly pine, longleaf pine, hardwoods, slash pine, hardwood/pine mix, and bald-cypress-water tupelo vegetation types of various age and size classes interspersed with sensitive DOE facilities and infrastructure.

This report is the culmination of multiple years of data acquisition and data preparation and summarizes geospatially modeled fire behavior for the Savannah River Site. The main objectives formulated at the beginning of this project were to clearly identify wildfire risk based on fuels, ignition patterns, and extreme weather conditions for the SRS and the surrounding areas and distinguish how prescribed fire and alternative silvicultural treatments can be effectively implemented to mitigate hazardous fuels relative to the primary natural resource objectives.

Prescribed fire objectives identified by the Savannah River Natural Resource Management Plan (May 2005) include:

1) Manage habitat for the endangered red-cockaded woodpecker to support recovery objectives

2) Reduce hazardous fuels to modify wildfire behavior to protect the public, firefighters, SRS personnel, and infrastructure

3) Restore and sustain fire-dependent savannah communities

4) Improve habitat for certain wildlife species

5) Enhance site preparation and remove grass thatch from waste caps.

In addition, resource constraints that may limit or complicate prescribed fire implementation were also identified:

1) Health issues and general complaints due to smoke as well as dispersion and regulatory compliance with air quality standards as mandated by the Clean Air Act

2) Uncertainty in weather predictions and possible difficulties in meeting prescriptive criteria due to wind direction, wind speed, temperature, and fuel moistures that are outside the desired range

3) Small ignition units, generally less than $500 \mathrm{ac}$, due to unit configuration and timing of other silviculture treatments

4) Administrative factors including stand-downs, mandatory meetings, national fire planning levels, and staff shortages.

Several fire behavior systems, founded on the Rothermel (Rothermel 1972) fire spread model, are available for deterministic and probabilistic geospatial fire modeling. Movement of one fire 
across a landscape can be modeled with FARSITE to determine where and with what type of fire behavior a fire will burn during a given time frame with changing weather conditions over time. FARSITE can be used during planning to determine changes in fire growth and behavior; however it is limited because it simulates fire from a specific origin. FSPro uses historic weather to develop the probability of a fire impacting different locations on the landscape. Again, because it models a particular fire origin across time, FSPro has limited utility in planning. FlamMap models fire behavior and burn probability for a whole landscape, regardless of ignition and is the most useful for assessing overall fire potential and identifying areas where fuel modification may be most beneficial.

In order to quantify current fire behavior potential within the SRS, deterministic and probabilistic geospatial fire analyses were performed using FlamMap. FlamMap is a spatial fire behavior system that simulates fire on a landscape of interest based on weather and fuels input. Fuel moistures are derived from weather information and can be fixed across the landscape or conditioned by wind and weather streams. Wind inputs have a fixed speed and direction or spatial wind grids that account for topographic influences on speed or direction (Finney 2006). Surface fire behavior fuel models, canopy cover, and topography (aspect, elevation, and slope) are required to model surface fire in FlamMap; in addition to the aforementioned data, canopy bulk density, canopy base height, and stand height are needed to model crown fire (refer to Appendix B for a glossary).

Daily and hourly weather data are readily available from various weather stations and can be quickly assembled and analyzed. Fuels data require significant effort to develop and are usually the limiting factor in the ability to adequately model fire behavior. A few regional and national efforts have provided seamless fuels information across the country. As with any large scale effort, the need to generalize often makes the data less accurate at a local scale. The most accurate fuels information is usually derived from intensive plot-based sampling; however interpolation is still required to create spatial data. This project assessed potential fire behavior derived from three fuels data sources: custom fuel models developed from Fuel Characteristic Classification System (FCCS) fuelbeds, Landscape Fire and Resource Management Planning Tool (LANDFIRE), and Southern Wildfire Risk Assessment (SWRA). SWRA and LANDFIRE are based on remotely sensed data while FCCS is based on intensive vegetation and fuels inventory from 629 plots within the SRS.

The Fuel Characteristic Classification System (FCCS) provides the ability to build custom fuelbeds including detailed vegetation and fuels structure and species composition based on individual fuelbed components. The FCCS was designed to be inclusive of all fuelbed categories including canopy, shrubs, non-woody fuels, woody fuels, litter-lichen-moss, and ground fuels stratums (Ottmar et al. 2007). The FCCS has been used for point fire behavior analyses and to explore fire effects, carbon assessments, and wildland fire smoke emissions (Sandberg et al. 2007; Ottmar and Prichard, in press). This system provides detailed plot-based vegetation and fuels inventory data which must be transformed to spatial data to perform geospatial fire behavior modeling using available systems such as FlamMap and FARSITE. 
Landscape Fire and Resource Management Planning Tools Project (LANDFIRE) is a multiagency effort that provides consistent vegetation and fuels data across all land ownerships for the U.S. at a resolution of $30 \mathrm{~m}$ (Reeves et al. 2009; Rollins 2009). The data were derived from Landsat Enhanced Thematic Mapper and Thematic Mapper satellite imagery acquired from 1999 to 2003 and informed by plot data (Reeves et al. 2009). LANDFIRE data include all fields and layers requisite for spatial fire behavior modeling (Rollins 2009). In addition, LANDFIRE includes numerous spatial vegetation classifications based on existing and potential vegetation and fire regimes.

The Southern Group of State Foresters along with cooperators from federal and state agencies responded to the need for seamless data to evaluate fire risk and related values at risk for the southern portion of the U.S. by creating the Southern Wildfire Risk Assessment (SWRA). SWRA data include canopy cover and surface fire behavior fuel models derived from vegetation data developed during the U.S. Geological Survey Gap Analysis Program which relied on $30 \mathrm{~m}$ satellite imagery acquired in the early 1990s from Landsat Thematic Mapper (Buckley et al. 2006). SWRA lacks canopy data required by the fire behavior systems to model crown fire activity. Unless canopy data are provided from another source, FlamMap uses one value for each canopy attribute across the entire landscape. Additional SWRA data include community risk rating and an index that measures wildfire risk.

This report provides a comparison of modeled fire behavior between the fuels data sources. Comparisons of fire behavior within each data source are also explored to evaluate effects of differing fuel moistures and wind speeds. In addition, the various characteristics of the data sources are explored to help managers determine which data may be most effective to address the identified land management objectives.

\section{Methods}

FlamMap provides deterministic and probabilistic fire behavior results which can be useful in determining areas where management may be beneficial or necessary and the relative effectiveness of treatment. Modeled fire behavior, specifically flame length, rate of spread, crown fire activity, and burn probabilities were compared between the three data sources. Flame length and rate of spread are most frequently used in fire management to understand the speed and intensity of a fire moving across a landscape, thereby supporting decisions for fire operations and to ensure safety. Crown fire activity indicates whether there is sufficient fire intensity to cause trees to torch or a fire to be sustained through the canopy; in addition, crown fire activity information can assist operational planning and indicate potential fire effects such as tree and stand mortality expected in areas that experience crown fire. Burn probabilities indicate the areas that have the greatest potential to burn. When these four characteristics are coupled, managers can determine where fire is predicted to exceed critical thresholds.

\section{Fuels and Topography}

Eight physical input themes are required to model surface fire, crown fire, and burn probabilities (refer to Appendix C). Topographical themes include slope, aspect, and elevation. Canopy data themes include canopy cover, canopy bulk density, canopy base height, and stand height; 
the final theme is surface fire behavior fuel models (FBFM). Landscape files for use in FlamMap were developed using these themes. Topographic themes were provided by digital elevation model (DEM) data while canopy and fuel model layers were developed from each of the three data sources. The extent for all simulations included a buffer around the SRS boundary to minimize the edge-effects from random ignitions while computing burn probabilities; all results were clipped to the study area boundary once simulations were complete.

FlamMap supports the 40 FBFM described by Scott and Burgan (2005) and the 13 FBFM described by Anderson (1982) as well as custom fuel models developed by the user when accompanied by a custom fuel model file delineating the necessary attributes. Local data were used to refine accuracy of fuel models for all data sources to ensure that non-burnable areas were consistent between data sources as well as retaining all originally classified non-burnable FBFM within each dataset. Developed areas were reclassified as FBFM 91, water bodies including lakes and rivers were reclassified as FBFM 98, all non-burnable roads were reclassified as FBFM 99, and 2-track roads consisting of grassy medians were reclassified as FBFM 101 (refer to Scott and Burgan (2005) for descriptions).

The FCCS includes inventoried and synthesized fuelbeds; this study is based on custom fuelbeds created from inventoried plot data and explores the applicability and utility of using plot data at the landscape-scale. Custom fuelbeds were developed for the study area based on intensive field sampling of 629 plots located in 6239 delineated stands in the study site (Andreu et al., in press). Regression relationships were developed from the plot fuel loadings and imputed to the stand polygon layer using stochastic prediction (Parresol et al., in review). Cluster analysis was conducted using the fire behavior for each stand as calculated within FCCS (Parresol et al., in review). Seven custom FBFM were created from stands closest to the centroid of each cluster analysis and were used to populate the spatial landscape data. As the FCCS data were only available for the SRS, LANDFIRE data augmented the area within the landscape boundary that was outside the SRS boundary.

LANDFIRE National version data were accessed using the LANDFIRE Data Access Tool (LFDAT), an interface tool functional in ArcMap. All eight themes necessary for analyses in FlamMap were downloaded. Both the 13 FBFM and the 40 FBFM were used to compare fire behavior.

SWRA uses the 13 FBFM plus four custom non-burnable fuel models to represent water, developed areas, agricultural areas, and barren areas. Canopy cover was categorized in five classes. Since SWRA lacks canopy data other than canopy cover, SWRA data were paired with canopy data from LANDFIRE and the stand data generated from FCCS to complete FlamMap analyses.

Landscape files (LCP) were built with the LANDFIRE Data Access Tool Raster Utilities function. Five separate LCP files were built: (1) FCCS with custom FBFM and canopy characteristics from local stand data, (2) LANDFIRE data using the 40 FBFM as described by Scott and Burgan (2005), (3) LANDFIRE data using the 13 FBFM as described by Anderson (1982), (4) SWRA 
data with LANDFIRE canopy data, and (5) SWRA data with canopy characteristics from local stand data.

\section{Weather and Fuel Moisture}

Analysis of historic recorded weather data from the Savannah River Remote Automated Weather Station (RAWS Station 383101) was completed using FireFamilyPlus (Bradshaw and Tirmenstein, in preparation). Data were analyzed for the spring fire season to determine ranges for fuel moisture and wind speed that support fire and roughly correspond to the $80^{\text {th }}$ and $97^{\text {th }}$ percentile weather for the period from February 20 to April 20, 1993 through 2009. The fuel moisture file specifies fuel moistures for 1-hr, 10-hr, and 100-hr timelag fuels, live herbaceous, and live woody fuels. Fuel moisture files were built to represent moderate conditions and dry conditions (Table 1). Twenty-foot wind speeds of $10 \mathrm{mph}$ and $30 \mathrm{mph}$ out of the southwest were used in combination with the moderate and dry fuel moisture scenarios to evaluate effects and identify important thresholds that influence fire behavior. The same fuel moisture, wind direction, and wind speed combinations were used for all data sources.

Table 1. Dead and live fuel moisture values

\begin{tabular}{|l|c|c|}
\hline \multicolumn{1}{|c|}{ Fuel Type } & Moderate & Dry \\
\hline 1-hr & $7 \%$ & $5 \%$ \\
\hline $\mathbf{1 0}-\mathbf{h r}$ & $10 \%$ & $7 \%$ \\
\hline $\mathbf{1 0 0}-\mathbf{h r}$ & $15 \%$ & $12 \%$ \\
\hline Live Herbaceous & $80 \%$ & $60 \%$ \\
\hline Live Woody & $140 \%$ & $110 \%$ \\
\hline
\end{tabular}

\section{FlamMap Analyses}

A FlamMap project was built for each LCP and four runs were simulated within each project to represent different fuel moisture and wind speed combinations: moderate fuel moistures with 10 $\mathrm{mph}$ and $30 \mathrm{mph}$ winds plus dry fuel moistures with $10 \mathrm{mph}$ and $30 \mathrm{mph}$ winds. All runs were modeled with southwest wind direction and the Scott/Reinhardt crown fire calculation method. Burn probabilities were analyzed with 2,000 random ignitions for 720 minutes (12 hours) per ignition.

Modeled crown fire activity (cfa), flame length (fl), rate of spread (ros), and burn probability (bp) were exported from FlamMap as ASCII files. The ASCII files were converted to grids and assigned the same projection as the input data (NAD 1983 UTM Zone 17N). As most of the outputs were floating point data, with the exception of crown fire activity, the data were converted to integer data and multiple fields were added to represent both English and metric units along with classes. Refer to Hollingsworth and Kurth (2010) for detailed explanation of methodology. 


\section{Results}

FlamMap simulation results examined include flame length, rate of spread, crown fire activity, and burn probabilities across the landscape. The results are presented to compare and contrast fire behavior within each dataset due to the influence of wind speed and fuel moisture. In addition, fire behavior results for the five datasets are explored. A comparison of fire behavior for each fire behavior fuel model has been included to allow local managers to be able to identify areas with rates of spread or flame lengths above an identified threshold. Results are presented using the following acronyms: FCCS for the Fuel Characteristic Classification System data, LF40 for LANDFIRE data using the 40 fire behavior fuel models, LF13 for LANDFIRE data using the 13 fire behavior fuel models, SRLF for Southern Wildfire Risk Assessment data combined with LANDFIRE canopy data, and SRSD for Southern Wildfire Risk Assessment data combined with canopy data from stand data.

\section{Landscape Results}

\section{Flame Length}

Mean flame length ranged from 1.2 to 2.3 feet with $10 \mathrm{mph}$ winds and 2.1 to 4.6 feet with 30 mph winds depending on fuel moisture conditions (Table 2 and Figures 1-4).

Table 2. Mean flame lengths for moderate and dry fuel moisture conditions

\begin{tabular}{|c||c|c||c|c||}
\hline \multicolumn{1}{|c||}{$\begin{array}{c}\text { Data } \\
\text { Source }\end{array}$} & $\begin{array}{c}\text { Moderate Cond. } \\
\text { 10 } \mathbf{m p h} \text { Wind }\end{array}$ & $\begin{array}{c}\text { Mry Cond. } \\
\mathbf{1 0} \text { mph Wind }\end{array}$ & $\begin{array}{c}\text { Moderate Cond. } \\
\mathbf{3 0} \mathbf{m p h} \text { Wind }\end{array}$ & $\begin{array}{c}\text { Dry Cond. } \\
\mathbf{3 0} \text { mph Wind }\end{array}$ \\
\hline FCCS & 2.0 & 2.3 & 3.6 & 4.4 \\
\hline LF40 & 1.8 & 2.2 & 3.2 & 4.6 \\
\hline LF13 & 1.2 & 1.6 & 2.1 & 2.7 \\
\hline SRLF & 1.4 & 1.6 & 2.4 & 3.2 \\
\hline SRSD & 1.3 & 1.7 & 2.6 & 3.4 \\
\hline
\end{tabular}

FCCS data consistently had the highest average flame length except for the combination of dry conditions with $30 \mathrm{mph}$ winds for which LF40 had a slightly longer average flame length. LF13 data had the lowest average flame length for all simulations. Wind speed appeared to have a greater effect on flame length than fuel moisture as the moderate conditions had greater average flame lengths with $30 \mathrm{mph}$ winds than dry conditions with $10 \mathrm{mph}$ winds.

Table 3. Maximum flame lengths for moderate and dry fuel moisture conditions

\begin{tabular}{|c||c|c||c|c||}
\hline \multirow{2}{*}{$\begin{array}{c}\text { Data } \\
\text { Source }\end{array}$} & $\begin{array}{c}\text { Moderate Cond. } \\
\text { 10 mph Wind }\end{array}$ & $\begin{array}{c}\text { Dry Cond. 10 } \\
\text { mph Wind }\end{array}$ & $\begin{array}{c}\text { Moderate Cond. } \\
\text { 30 mph Wind }\end{array}$ & $\begin{array}{c}\text { Dry Cond. 30 } \\
\text { mph Wind }\end{array}$ \\
\hline FCCS & 23.6 & 34.8 & 76.8 & 93.2 \\
\hline LF40 & 20.3 & 25.3 & 49.5 & 86.9 \\
\hline LF13 & 25.6 & 31.5 & 68.6 & 84.3 \\
\hline SRLF & 11.8 & 13.5 & 22.6 & 25.6 \\
\hline SRSD & 22.0 & 28.9 & 93.8 & 112.2 \\
\hline
\end{tabular}


Figure 1. Flame lengths for moderate fuel moisture conditions and $10 \mathrm{mph}$ wind
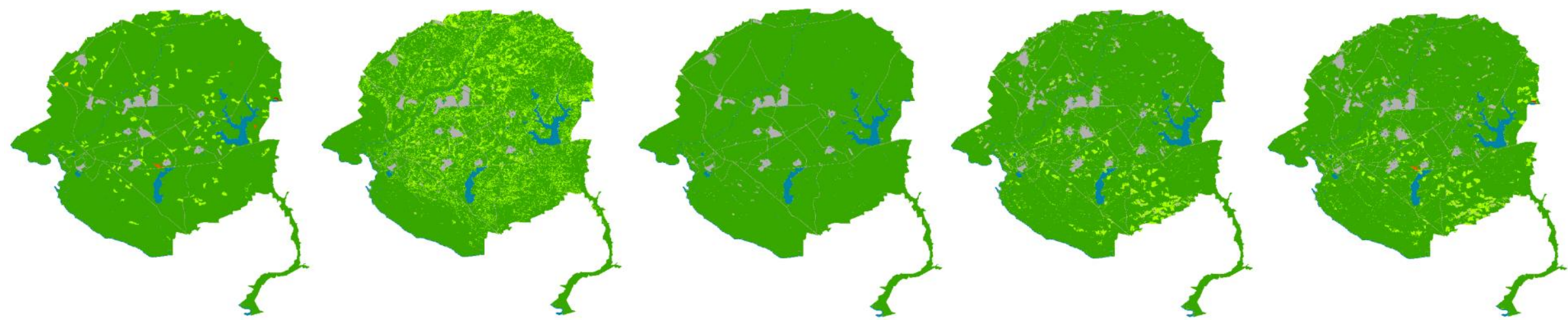

FCCS

LF40

LF13

SRLF

SRSD

Figure 2. Flame lengths for moderate fuel moisture conditions and $30 \mathrm{mph}$ wind
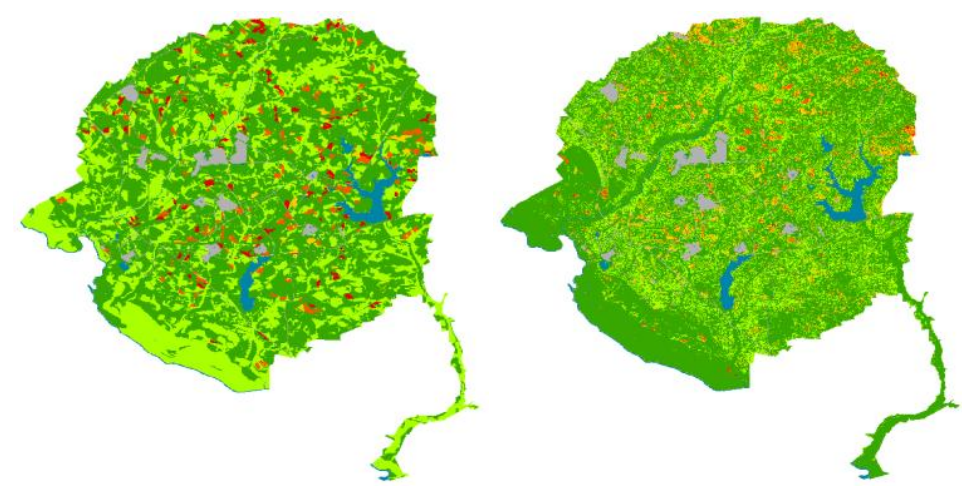

FCCS
LF40

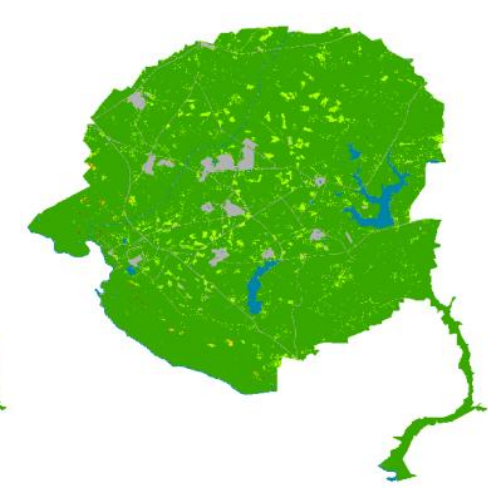

LF13

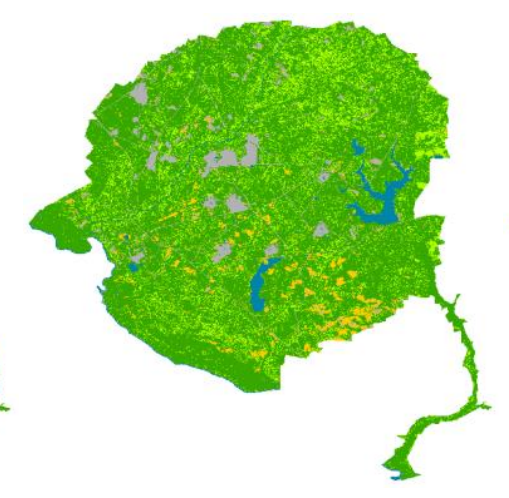

SRLF

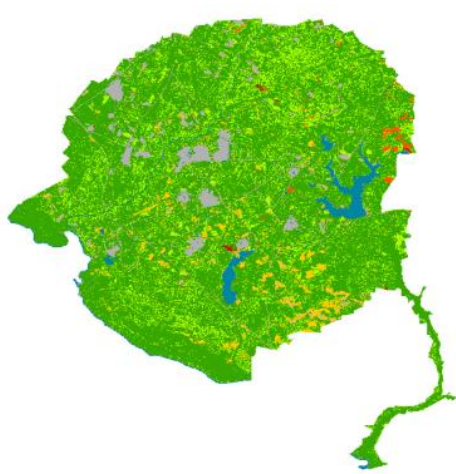

SRSD

Flame Length $0-4 \mathrm{ft}$ $4-8 \mathrm{ft}$ $8-11 \mathrm{ft}$ $11-20 \mathrm{ft}$ $=20 \mathrm{ft}$ water non-burnable 
Figure 3. Flame lengths for dry fuel moisture conditions and $10 \mathrm{mph}$ wind
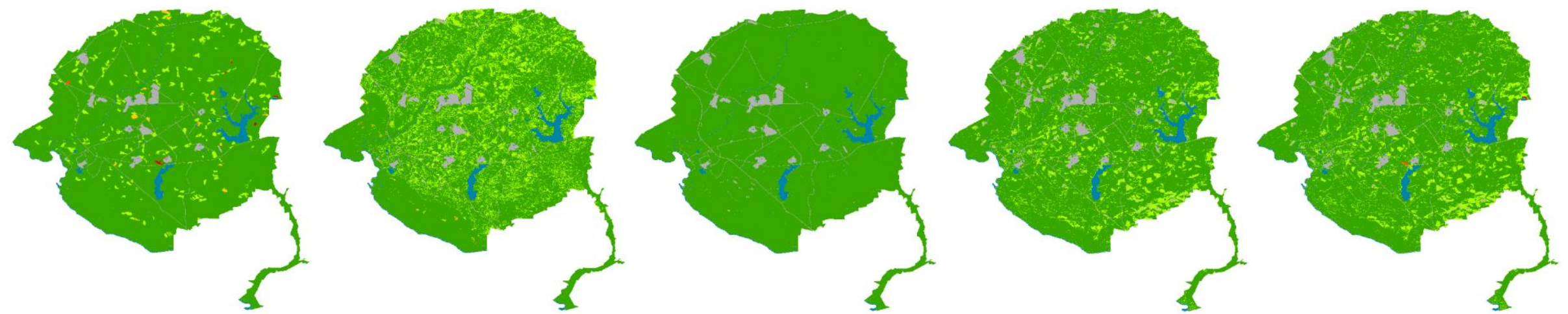

FCCS

LF40

LF13

SRLF

SRSD

Figure 4. Flame lengths for dry fuel moisture conditions and $30 \mathrm{mph}$ wind

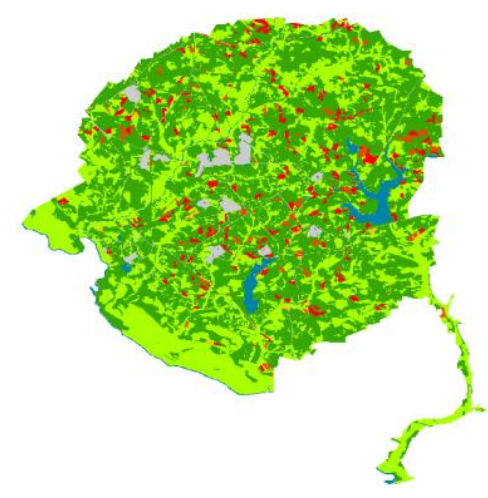

FCCS

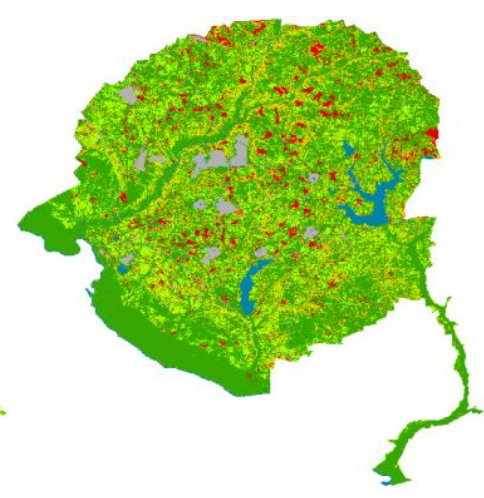

LF40

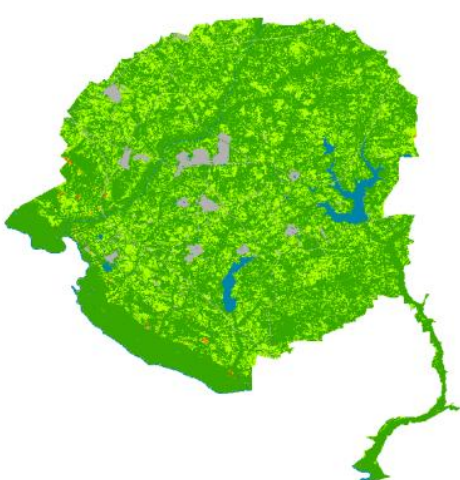

LF13

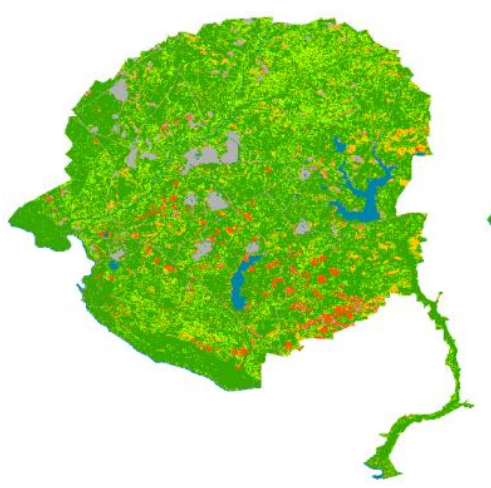

SRLF

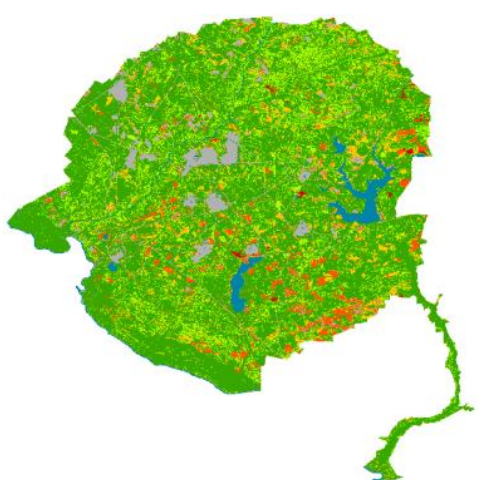

SRSD

\section{Flame Length}

$0-4 \mathrm{ft}$

$4-8 \mathrm{ft}$ $8-11 \mathrm{ft}$

$11-20 \mathrm{ft}$

$>20 \mathrm{ft}$ water

non-burnable 
Maximum flame lengths ranged from 11.8 to 34.8 feet for $10 \mathrm{mph}$ winds and 22.6 to 112.2 feet for 30 mph winds (Table 3). SRSD had the highest maximum flame length when simulations were analyzed with $30 \mathrm{mph}$ winds, but there was little consistency between maximum flame length and data source for simulations with $10 \mathrm{mph}$ winds. SRLF consistently had the lowest maximum flame length for all simulations.

Evaluating flame length by class allows the ability to discern the influence of fuel moisture and wind but also allows for comparison between data source (Table 4). For example, a local trigger point could set a threshold flame length of $8 \mathrm{ft}$. All areas predicted to have flame lengths greater than $8 \mathrm{ft}$ would be identified for treatment. However, resulting potential treatment areas would be quite different depending on the data source.

Table 4. Flame length classes by proportion of total SRS for moderate and dry fuel moisture conditions

\begin{tabular}{|c|c|c|c|c|c|}
\hline \multirow{2}{*}{$\begin{array}{c}\text { Data } \\
\text { Source }\end{array}$} & \multirow{2}{*}{$\begin{array}{c}\text { Flame } \\
\text { Length } \\
\text { Class } \\
\end{array}$} & \multicolumn{2}{|c|}{$10 \mathrm{mph}$ Wind Speed } & \multicolumn{2}{|c|}{$30 \mathrm{mph}$ Wind Speed } \\
\hline & & Moderate Cond. & Dry Cond. & Moderate Cond. & Dry Cond. \\
\hline \multirow[t]{5}{*}{ FCCS } & $0-4 \mathrm{ft}$ & $91 \%$ & $90 \%$ & $56 \%$ & $53 \%$ \\
\hline & $4-8 \mathrm{ft}$ & $3 \%$ & $4 \%$ & $34 \%$ & $36 \%$ \\
\hline & $8-11 \mathrm{ft}$ & & & $1 \%$ & \\
\hline & $11-20 \mathrm{ft}$ & & & $2 \%$ & $2 \%$ \\
\hline & $>20 \mathrm{ft}$ & & & $2 \%$ & $4 \%$ \\
\hline \multirow[t]{5}{*}{ LF40 } & $0-4 \mathrm{ft}$ & $78 \%$ & $76 \%$ & $66 \%$ & $59 \%$ \\
\hline & $4-8 \mathrm{ft}$ & $16 \%$ & $18 \%$ & $21 \%$ & $17 \%$ \\
\hline & $8-11 \mathrm{ft}$ & & & $6 \%$ & $13 \%$ \\
\hline & $11-20 \mathrm{ft}$ & & & $1 \%$ & \\
\hline & $>20 \mathrm{ft}$ & & & & $5 \%$ \\
\hline \multirow[t]{5}{*}{ LF13 } & $0-4 \mathrm{ft}$ & $94 \%$ & $94 \%$ & $89 \%$ & $68 \%$ \\
\hline & $4-8 \mathrm{ft}$ & & & $5 \%$ & $25 \%$ \\
\hline & $8-11 \mathrm{ft}$ & & & & \\
\hline & $11-20 \mathrm{ft}$ & & & & \\
\hline & $>20 \mathrm{ft}$ & & & & \\
\hline \multirow[t]{5}{*}{ SRLF } & $0-4 \mathrm{ft}$ & $89 \%$ & $82 \%$ & $72 \%$ & $66 \%$ \\
\hline & $4-8 \mathrm{ft}$ & $4 \%$ & $10 \%$ & $16 \%$ & $16 \%$ \\
\hline & $8-11 \mathrm{ft}$ & & & $4 \%$ & $7 \%$ \\
\hline & $11-20 \mathrm{ft}$ & & & & $4 \%$ \\
\hline & $>20 \mathrm{ft}$ & & & & \\
\hline \multirow[t]{5}{*}{ SRSD } & $0-4 \mathrm{ft}$ & $88 \%$ & $82 \%$ & $71 \%$ & $65 \%$ \\
\hline & $4-8 \mathrm{ft}$ & $4 \%$ & $10 \%$ & $16 \%$ & $16 \%$ \\
\hline & $8-11 \mathrm{ft}$ & & & $4 \%$ & $7 \%$ \\
\hline & $11-20 \mathrm{ft}$ & & & $1 \%$ & $5 \%$ \\
\hline & $>20 \mathrm{ft}$ & & & & \\
\hline
\end{tabular}

Note: For any particular data source, totals do not add to $100 \%$ due to non-burnable fuels. Although non-burnable fuel models were adjusted for each data source, the non-burnable fuel models as classified in the original data for each source were retained. 


\section{Rate of Spread}

Mean rate of spread ranged from 1.6 to 3.8 chains/hour for $10 \mathrm{mph}$ winds and 5.3 to 17.2 chains/hour for $30 \mathrm{mph}$ winds (Table 5 and Figures 5-8). LF13 had the lowest mean rate of spread with $10 \mathrm{mph}$ winds and FCCS data had the lowest mean rate of spread with $30 \mathrm{mph}$ winds. SRSD and SRLF data sources had the highest mean rate of spread. Wind speed appeared to have a greater effect on rate of spread than fuel moisture as the moderate conditions had higher average rates of spread with $30 \mathrm{mph}$ winds than dry conditions with 10 mph winds.

Table 5. Mean rate of spread for moderate and dry fuel moisture conditions

\begin{tabular}{|c||c|c||c|c||}
\hline \multicolumn{1}{|c||}{$\begin{array}{c}\text { Data } \\
\text { Source }\end{array}$} & $\begin{array}{c}\text { Moderate Cond. } \\
\mathbf{1 0} \text { mph Wind }\end{array}$ & $\begin{array}{c}\text { Dry Cond. } \\
\mathbf{1 0} \text { mph Wind }\end{array}$ & $\begin{array}{c}\text { Moderate Cond. } \\
\text { 30 } \mathbf{~ m h ~ W i n d ~}\end{array}$ & $\begin{array}{c}\text { Dry Cond. } \\
\mathbf{3 0} \text { mph Wind }\end{array}$ \\
\hline FCCS & 1.9 & 2.4 & 5.3 & 7.2 \\
\hline LF40 & 2.1 & 3.0 & 6.7 & 10.1 \\
\hline LF13 & 1.6 & 2.3 & 5.7 & 8.1 \\
\hline SRLF & 2.5 & 3.7 & 11.5 & 17.0 \\
\hline SRSD & 2.5 & 3.8 & 11.4 & 17.2 \\
\hline
\end{tabular}

Maximum rates of spread range from 15.8 to 113 chains/hour for $10 \mathrm{mph}$ winds and 69.8 to 450.4 chains/hour for simulations with $30 \mathrm{mph}$ winds (Table 6). SRLF and SRSD had the highest maximum rate of spread for all simulations regardless of fuel moisture and winds. The FCCS data had the lowest maximum rate of spread for all simulations by a substantial margin.

Table 6. Maximum rate of spread for moderate and dry fuel moisture conditions

\begin{tabular}{|c|c|c|c|c|}
\hline \multirow[b]{2}{*}{$\begin{array}{l}\text { Data } \\
\text { Source }\end{array}$} & \multicolumn{4}{|c|}{ Mean Rate of Spread (chains/hr) } \\
\hline & $\begin{array}{l}\text { Moderate Cond. } \\
10 \mathrm{mph} \text { Wind }\end{array}$ & $\begin{array}{l}\text { Dry Cond. } \\
10 \mathrm{mph} \text { Wind }\end{array}$ & $\begin{array}{l}\text { Moderate Cond. } \\
30 \mathrm{mph} \text { Wind }\end{array}$ & $\begin{array}{l}\text { Dry Cond. } \\
30 \mathrm{mph} \text { Wind }\end{array}$ \\
\hline FCCS & 15.8 & 20.9 & 69.8 & 91.0 \\
\hline LF40 & 59.1 & 107.4 & 216.8 & 393.7 \\
\hline LF13 & 93.1 & 109.8 & 378.8 & 447.4 \\
\hline SRLF & 95.7 & 113.0 & 381.5 & 450.4 \\
\hline SRSD & 95.7 & 113.0 & 381.5 & 450.4 \\
\hline
\end{tabular}


Figure 5. Rates of spread for moderate fuel moisture conditions and $10 \mathrm{mph}$ wind

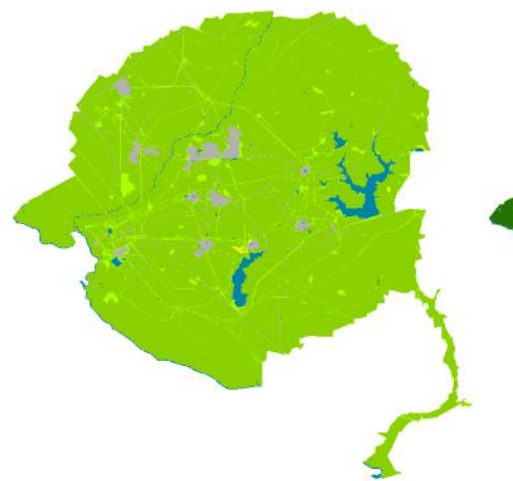

FCCS

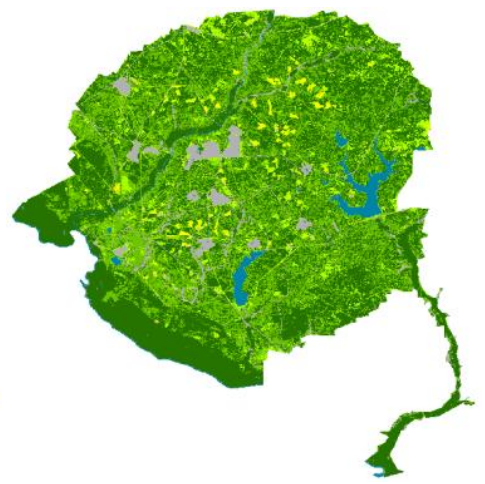

LF40

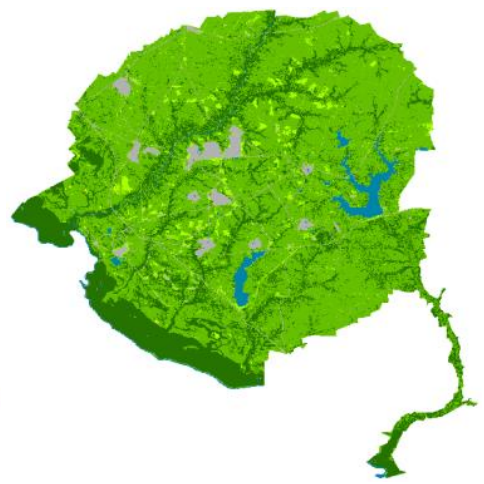

LF13

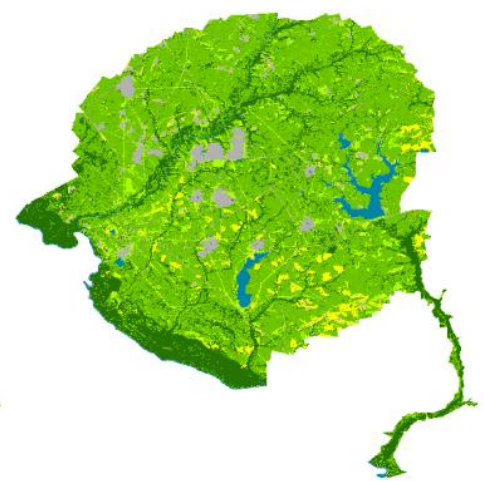

SRLF

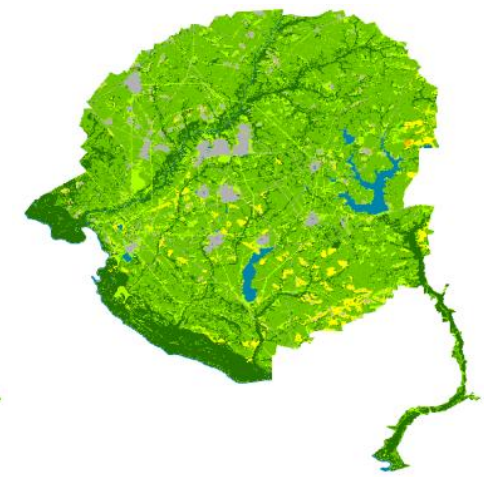

SRSD

Figure 6. Rates of spread for moderate fuel moisture conditions and $30 \mathrm{mph}$ wind

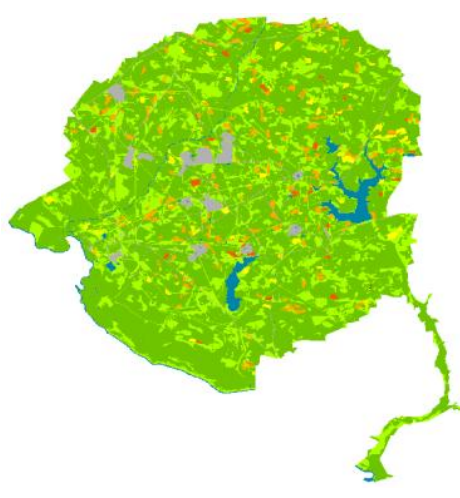

FCCS

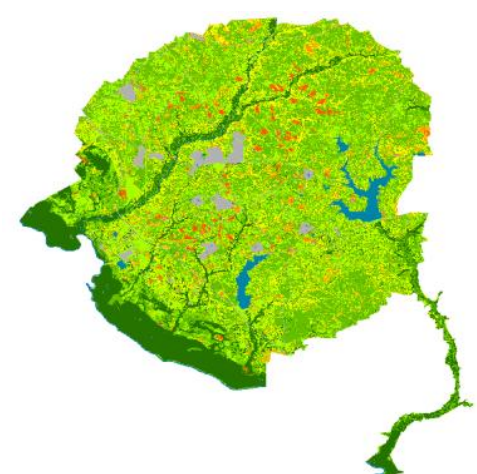

LF40

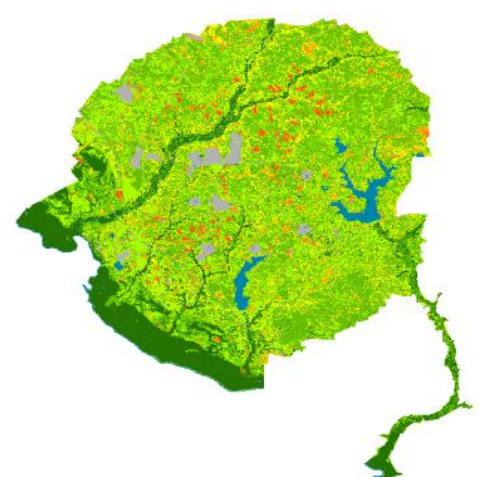

LF13

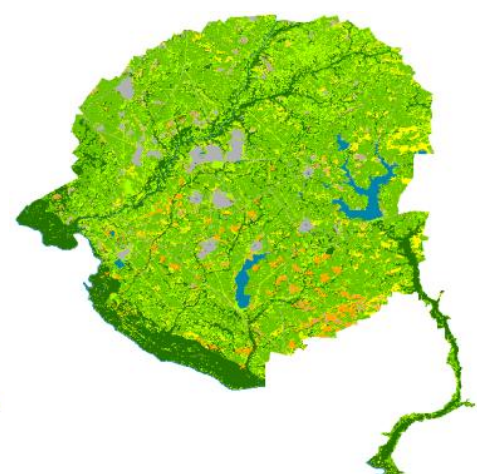

SRLF

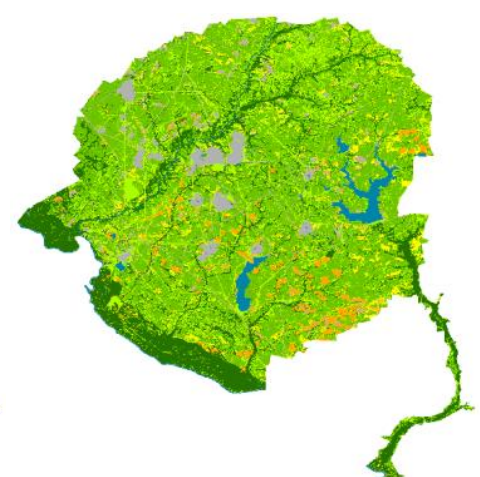

SRSD 
Figure 7. Rates of spread for dry fuel moisture conditions and $10 \mathrm{mph}$ wind
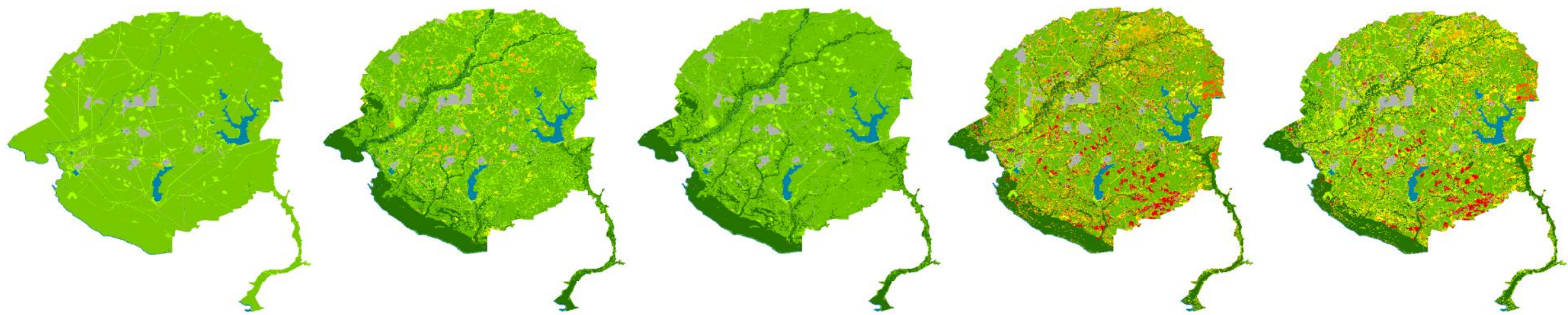

FCCS

LF40

LF13

SRLF

SRSD

Figure 8. Rates of spread for dry fuel moisture conditions and $30 \mathrm{mph}$ wind

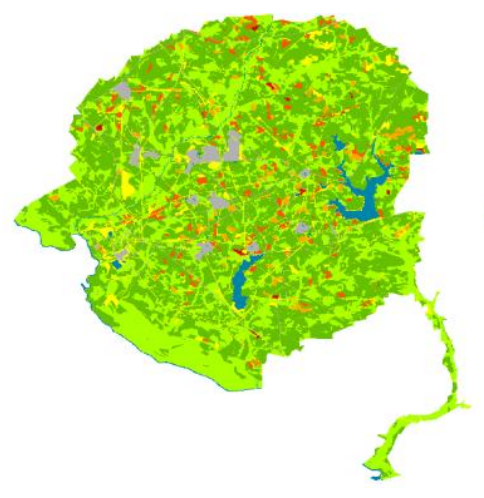

FCCS

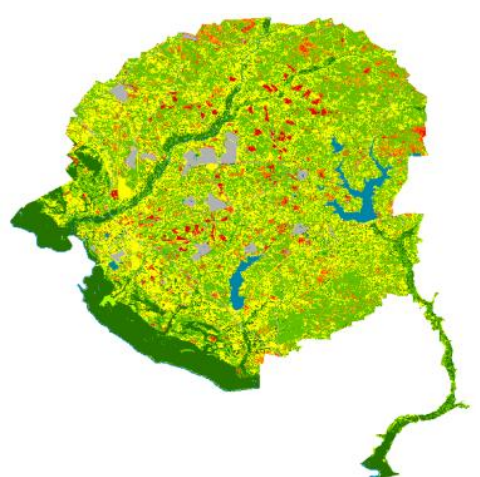

LF40

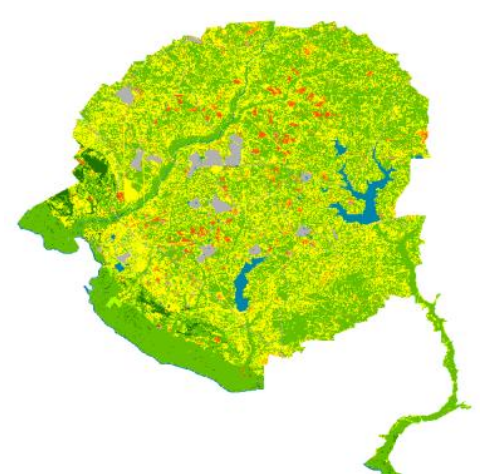

LF13

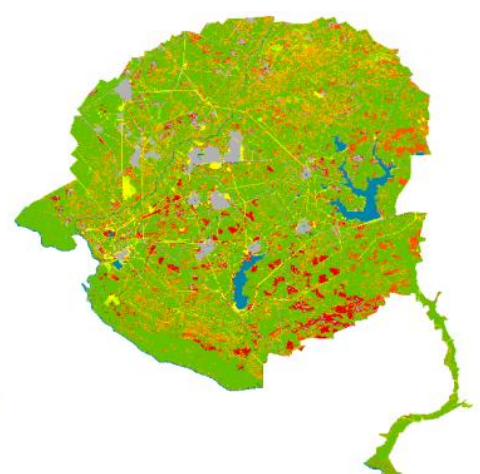

SRLF

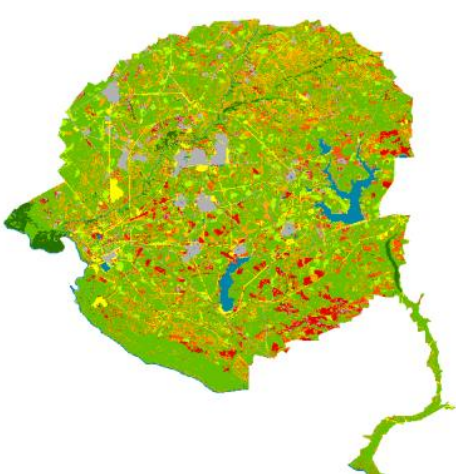

SRSD 


\section{Crown Fire Activity}

FlamMap crown fire activity classes include surface fire, torching or passive crown fire, and active crown fire. Torching is indicated where the surface fire is of sufficient intensity relative to height of the canopy fuels. Active crown fire is modeled where torching is possible and the canopy is sufficiently dense to support fire movement relative to the wind speed. Crown fire was less than 1 percent of the landscape regardless of wind speed and fuel moisture. SRLF and LF13 data produced only surface fire regardless of fuel moisture and wind (Table 7). FCCS and SRSD produced some torching even with moderate fuel moisture values and low wind speed. LF40 data produced some torching, but only with $30 \mathrm{mph}$ winds. All data sources produced small amounts of crown fire under dry fuel conditions and $30 \mathrm{mph}$ winds except for SRLF data.

Table 7. Crown fire activity by proportion of total SRS for moderate and dry fuel moisture conditions

\begin{tabular}{|c|c|c|c|c|c|c|c|c|}
\hline \multirow{3}{*}{$\begin{array}{c}\text { Data } \\
\text { Source }\end{array}$} & \multicolumn{4}{|c|}{$10 \mathrm{mph}$ Wind Speed } & \multicolumn{4}{|c|}{$30 \mathrm{mph}$ Wind Speed } \\
\hline & \multicolumn{2}{|c|}{ Moderate Cond. } & \multicolumn{2}{|c|}{ Dry Cond. } & \multicolumn{2}{|c|}{ Moderate Cond. } & \multicolumn{2}{|c|}{ Dry Cond. } \\
\hline & Surface & Torching & Surface & Torching & Surface & Torching & Surface & Torching \\
\hline FCCS & $91 \%$ & $4 \%$ & $91 \%$ & $4 \%$ & $89 \%$ & $5 \%$ & $89 \%$ & $5 \%$ \\
\hline LF40 & $94 \%$ & & $94 \%$ & & $92 \%$ & $2 \%$ & $89 \%$ & $5 \%$ \\
\hline LF13 & $94 \%$ & & $94 \%$ & & $94 \%$ & & $94 \%$ & \\
\hline SRLF & $92 \%$ & & $92 \%$ & & $92 \%$ & & $92 \%$ & \\
\hline SRSD & $91 \%$ & $1 \%$ & $90 \%$ & $2 \%$ & $89 \%$ & $2 \%$ & $89 \%$ & $3 \%$ \\
\hline
\end{tabular}

Note: For any particular data source, totals do not add to $100 \%$ due to non-burnable fuels. Although non-burnable fuel models were adjusted for each data source, the non-burnable fuel models as classified in the original data for each source were retained.

\section{Burn Probabilities}

FlamMap calculates burn probabilities by simulating fire growth for a number of randomly located ignitions for a specified period of time. The ratio of fires burning a pixel to the total number of fires simulated computes the burn probability for that pixel. Burn probability is related to the distribution of fire size which is related to the rates of spread and the fuel continuity. For management purposes, burn probabilities are best suited for identifying high probability areas where management actions may be most effective in achieving resource and protection objectives. Burn probabilities are useful in planning and may change during the process of calibrating data. If FBFM or canopy characteristics are significantly modified, the areas of highest burn probability may be different than with uncalibrated data. If only minor or localized changes to the landscape layers are necessary, calculated probabilities may slightly differ but the relative location of highest and lowest burn probability is likely to vary little.

Burn probabilities ranged between 0.002 to 0.007 for moderate fuel moistures and 0.0035 to 0.0135 for dry fuel conditions (Figures 9-12). LF13 had the lowest burn probabilities with 10 $\mathrm{mph}$ winds while FCCS had the lowest burn probability with $30 \mathrm{mph}$ winds. SRSD had the highest burn probabilities for $30 \mathrm{mph}$ winds; there was little consistency for simulations modeled with $10 \mathrm{mph}$ winds. The relatively low probabilities suggest that fire spread is limited in the SRS which is consistent with actual fire sizes historically observed. 
Figure 9. Burn probabilities for moderate fuel moisture conditions and $10 \mathrm{mph}$ wind
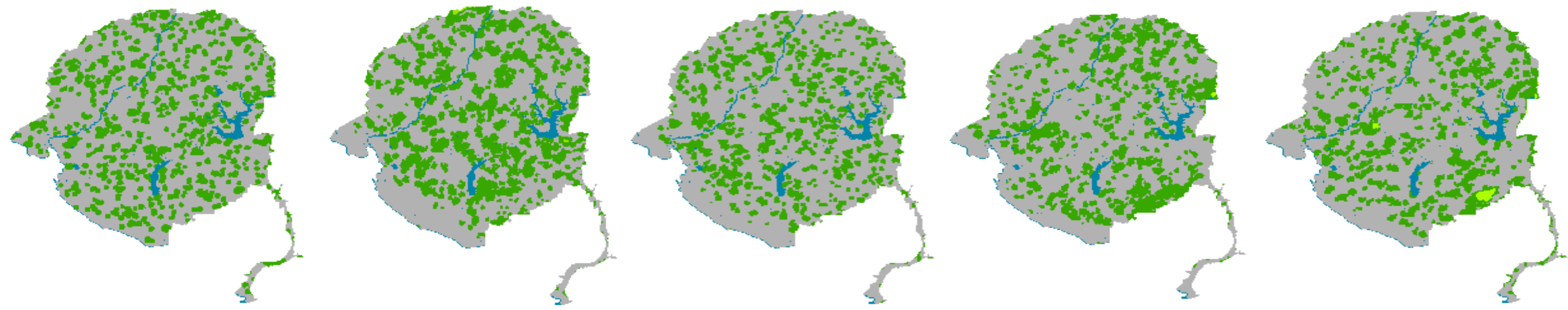

FCCS

LF40

LF13

SRLF

SRSD

Figure 10. Burn probabilities for moderate fuel moisture conditions and $30 \mathrm{mph}$ wind

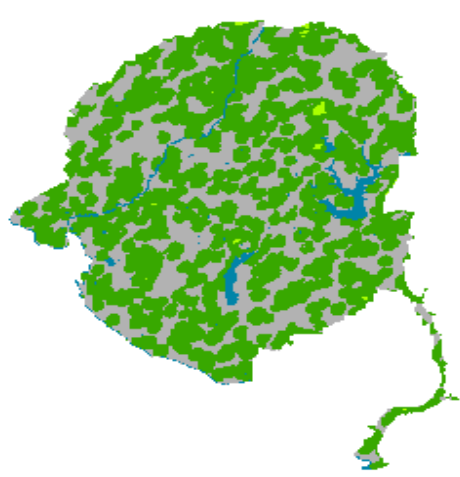

FCCS

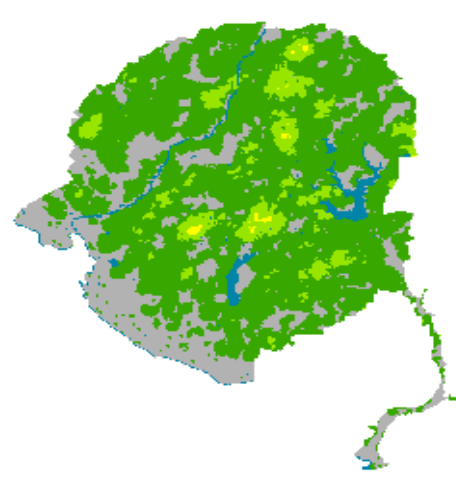

LF40

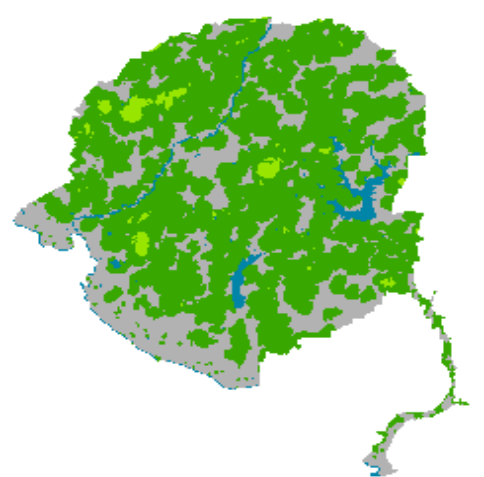

LF13

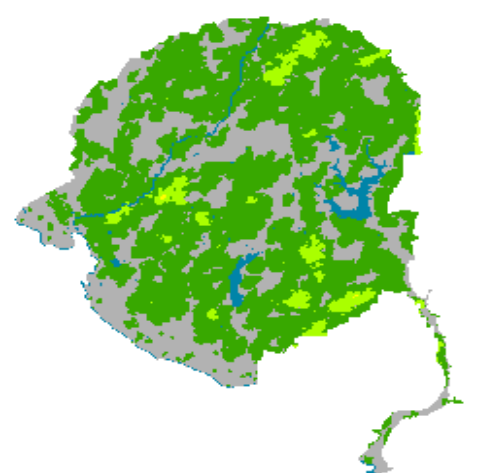

SRLF

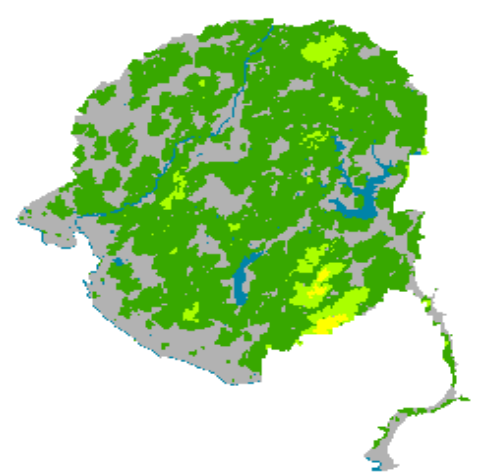

SRSD

Bum Probabilities

$0-0.0025$

$\square 0.0025-0.005$

$\square 0.005-0.0075$

$0.0075-0.01$

$0.01-0.0125$

$0.0125-0.0150$

water 
Figure 11. Burn probabilities for dry fuel moisture conditions and $10 \mathrm{mph}$ wind

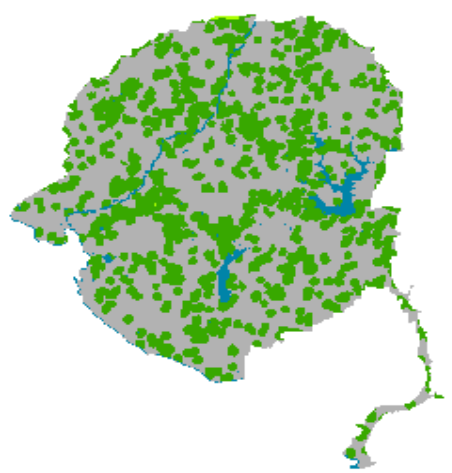

FCCS

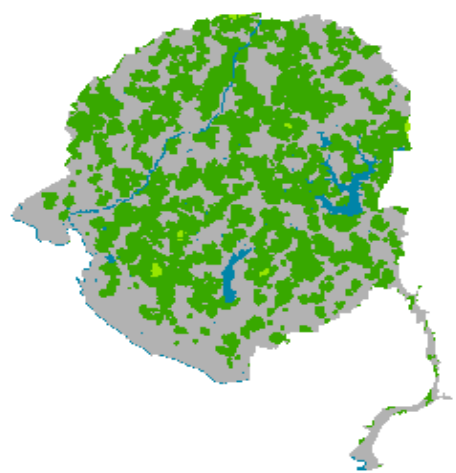

LF40

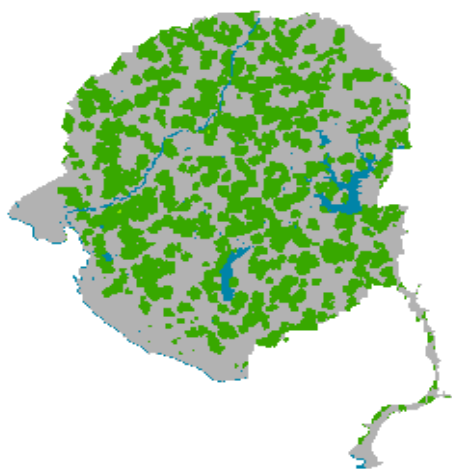

LF13

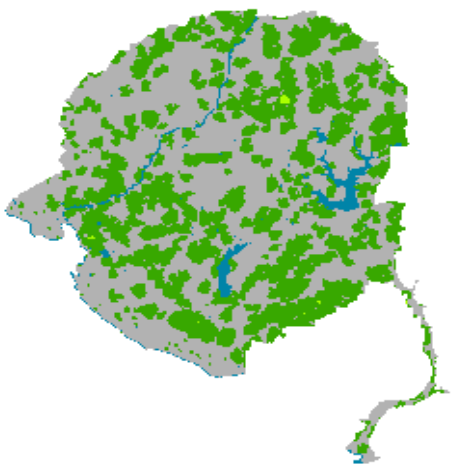

SRLF

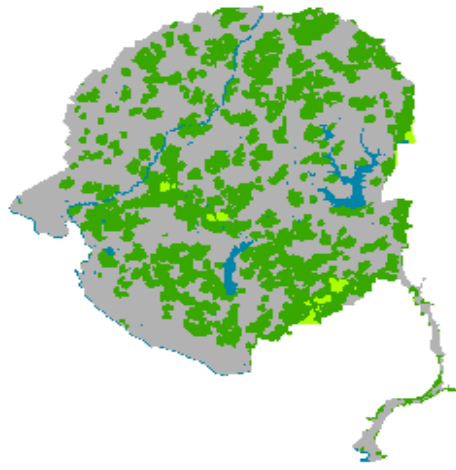

SRSD

Figure 12. Burn probabilities for dry fuel moisture conditions and $30 \mathrm{mph}$ wind

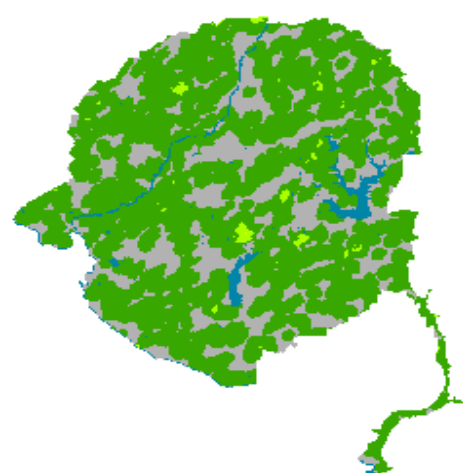

FCCS

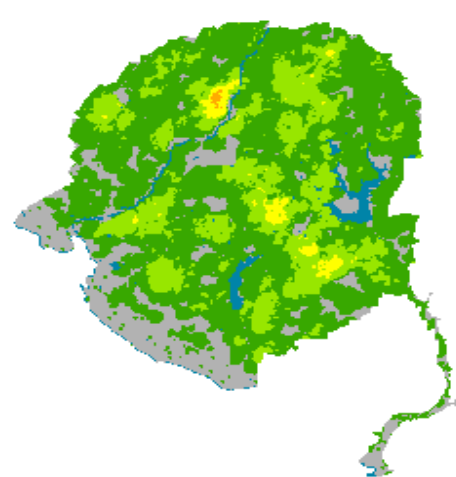

LF40

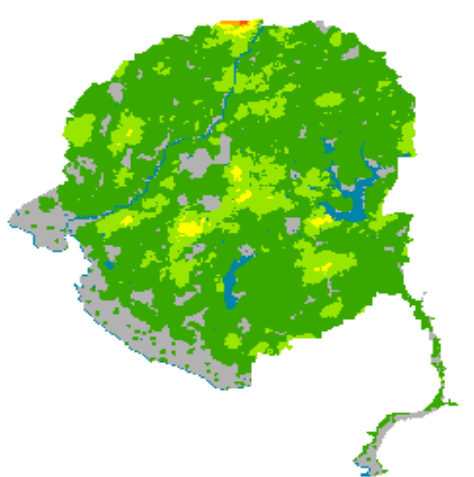

LF13

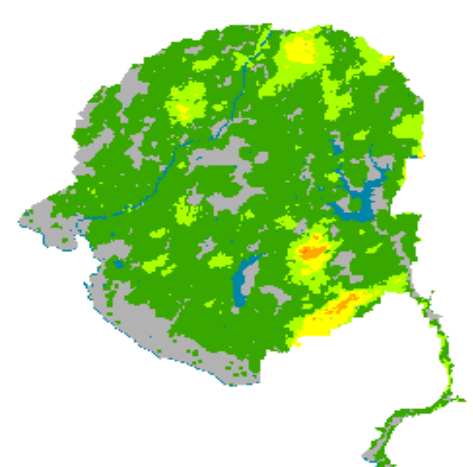

SRLF

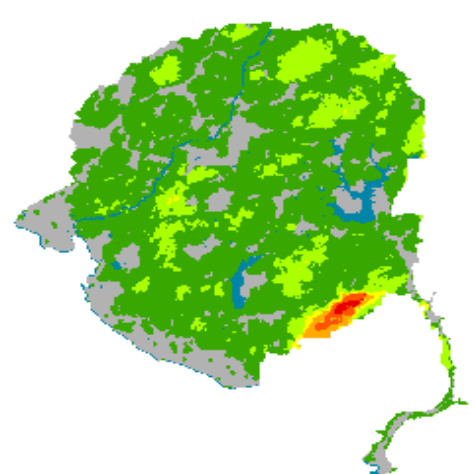

SRSD

Bum Probabilities

$0-0.0025$

$\square 0.0025-0.005$

$\square 0.005-0.0075$

$0.0075-0.01$

$0.01-0.0125$

$0.0125-0.0150$

water 


\section{Surface Fire Behavior Fuel Models Results}

An additional method to quantify fire behavior is to evaluate fire behavior for each surface fire behavior fuel model. Flame lengths and rates of spread above acceptable thresholds set by local managers can be identified as well as evaluating candidate areas for potential treatments in order to modify expected post-implementation fire behavior to be within an identified acceptable range. Mean flame length and rate of spread values are presented for LF40, LF13, SRLF, and SRSD data sources. Custom fuel models developed for modeling FCCS are based on modeled FCCS fire behavior and are difficult to translate to observed fuels on the ground; therefore they are not included in this analysis. Approximately 6 percent of the SRS is classified as non-burnable using LANDFIRE data and 8 percent with SWRA data. Areas classified as non-burnable are not discussed further. Because little torching or crown fire was modeled across the landscape, an analysis by fuel model on the effects to crown fire activity is insignificant. Burn probability, while related to fuel model, is dependent on movement across the landscape and is best assessed at the landscape level. Refer to the fire characteristics charts (Figure 13) prepared for the four data sources to compare fire behavior.

\section{Flame Length}

To evaluate flame length potential, it can be useful to explore modeled fire behavior by surface fire behavior fuel model. Many surface fuel models will have fairly benign flame lengths regardless of fuel moisture conditions or winds. Flame length classes discussed are based upon classes described in the Fire Behavior Characteristics Chart (also known as the Hauling chart) that correlate with fire suppression tactics and resource assignment. Flame lengths less than 4 feet can generally be directly attacked by firefighters, whereas flame lengths between 4 and 8 feet can be fought using equipment such as dozers and skidgeons, and flame lengths greater than 11 feet can be fought using aerial resources such as helicopters or air tankers.

Flame length within SRS is modeled to be less than 4 feet for the majority of the landscape, regardless of data set, for all conditions. Even with dry fuel moistures and $30 \mathrm{mph}$ winds, about 59 percent of the landscape would have mean flame lengths less than 4 feet when modeled with either LF40 or LF13 (Tables 8 and 9). With dry fuel moistures and winds of $30 \mathrm{mph}$, approximately 18 percent of the SRS would have flame lengths greater than 8 feet using LF40 data while less than 1 percent of the SRS would have flame lengths greater than 8 feet using LF13 data. The shrub and grass communities are predicted to have the highest flame lengths; however, a substantial difference exists in the total area classified as grass or shrub (FBFM $105,108,147,149)$ using the 40 FBFM versus the 13 FBFM (FBFM 3, 4) expected to have flame lengths greater than 8 feet.

SRLF and SRSD results by surface fuel model are quite similar, with the exception of FBFM 6 and 7 which have mean flame lengths that are substantially different between the data sources (Tables 10 and 11). This is a result of the difference in canopy characteristics between the data sources. Both SWRA data sources have mean flame lengths less than 4 feet for about 66 percent of the SRS area with low fuel moistures and $30 \mathrm{mph}$ winds. Approximately 7 percent of the SRS would have flame lengths greater than 8 feet with low fuel moistures and $30 \mathrm{mph}$ winds with SRLF and SRSD data. 
Table 8. Mean flame length by surface fuel model for LANDFIRE 40 FBFM

\begin{tabular}{|c|c|c|c|c|c|c|}
\hline \multicolumn{2}{|r|}{ LANDFIRE - 40 FBFM } & \multicolumn{5}{|c|}{ Mean Flame Length (ft) } \\
\hline FBFM & Description & $\begin{array}{l}\text { Moderate } \\
\text { Cond. } 10 \\
\text { mph Wind }\end{array}$ & $\begin{array}{c}\text { Dry Cond. } \\
10 \mathrm{mph} \\
\text { Wind }\end{array}$ & $\begin{array}{c}\text { Moderate } \\
\text { Cond. } 30 \\
\text { mph Wind }\end{array}$ & $\begin{array}{c}\text { Dry Cond. } \\
30 \mathrm{mph} \\
\text { Wind }\end{array}$ & $\begin{array}{c}\text { SRS } \\
\text { Proportion } \\
(\%) \\
\end{array}$ \\
\hline 101 & Short Sparse Grass & 0.8 & 1.0 & 1.2 & 1.8 & 4 \\
\hline 105 & Short Grass & 4.3 & 6.2 & 9.9 & 24.8 & 5 \\
\hline 108 & Tall Coarse Grass & 16.7 & 23.9 & 30.2 & 43.3 & $<1$ \\
\hline 147 & Tall Shrub, Shrub Litter & 4.9 & 5.7 & 8.5 & 11.6 & 13 \\
\hline 149 & Tall Shrub, Shrub Litter, Fine Fuels & 8.4 & 10.6 & 29.6 & 48.2 & $<1$ \\
\hline 161 & Timber-Grass-Shrub Low Load) & 0.3 & 0.7 & 0.3 & 1.3 & 2 \\
\hline 163 & Timber-Grass-Shrub (Moderate Load) & 2.3 & 3.0 & 4.1 & 5.1 & 17 \\
\hline 182 & Broadleaf Litter (Low Load) & 0.3 & 0.3 & 0.7 & 0.7 & 14 \\
\hline 186 & Broadleaf Litter (Moderate Load) & 1.1 & 1.3 & 1.9 & 2.1 & 39 \\
\hline
\end{tabular}

Table 9. Mean flame length by surface fuel model for LANDFIRE 13 FBFM

\begin{tabular}{|c|l||c|c||c|c||c||}
\hline \multicolumn{2}{|c||}{ LANDFIRE - 13 FBFM } & \multicolumn{5}{c||}{ Mean Flame Length (ft) } \\
\hline \multicolumn{1}{|c|}{ FBFM } & \multicolumn{1}{|c||}{ Description } & $\begin{array}{c}\text { Moderate } \\
\text { Cond. 10 } \\
\text { mph Wind }\end{array}$ & $\begin{array}{c}\text { Dry Cond. } \\
\mathbf{1 0} \text { mph } \\
\text { Wind }\end{array}$ & $\begin{array}{c}\text { Moderate } \\
\text { Cond. 30 } \\
\text { mph Wind }\end{array}$ & $\begin{array}{c}\text { Dry Cond. } \\
\mathbf{3 0} \text { mph } \\
\text { Wind }\end{array}$ & $\begin{array}{c}\text { SRS } \\
\text { Proportion } \\
\text { (\%) }\end{array}$ \\
\hline $\mathbf{2}$ & Grass & 2.6 & 3.1 & 5.9 & 6.7 & 5 \\
\hline $\mathbf{3}$ & Tall Grass & 11.8 & 13.5 & 22.6 & 25.3 & $<1$ \\
\hline $\mathbf{4}$ & Mature Shrubs (>6 ft) & 9.9 & 12.3 & 34.5 & 48.0 & $<1$ \\
\hline $\mathbf{5}$ & Young Shrubs & 1.0 & 2.3 & 1.7 & 4.1 & 13 \\
\hline $\mathbf{7}$ & Southern Rough & 2.3 & 2.6 & 3.6 & 4.3 & 17 \\
\hline $\mathbf{8}$ & Timber Litter & 0.4 & 0.7 & 0.7 & 1.0 & 16 \\
\hline $\mathbf{9}$ & Hardwood Litter & 1.3 & 1.3 & 2.0 & 2.2 & 39 \\
\hline $\mathbf{1 0 1}$ & Short Sparse Grass & 0.8 & 1.0 & 1.2 & 1.8 & 4 \\
\hline
\end{tabular}

Table 10. Mean flame length by surface fuel model for SWRA data with LANDFIRE canopy data

\begin{tabular}{|c|c|c|c|c|c|c|}
\hline \multicolumn{2}{|r|}{ SWRA/LANDFIRE - 13 FBFM } & \multicolumn{5}{|c|}{ Mean Flame Length (ft) } \\
\hline FBFM & Description & $\begin{array}{c}\text { Moderate } \\
\text { Cond. } 10 \\
\text { mph Wind }\end{array}$ & $\begin{array}{l}\text { Dry Cond. } \\
10 \mathrm{mph} \\
\text { Wind } \\
\end{array}$ & $\begin{array}{l}\text { Moderate } \\
\text { Cond. } 30 \\
\text { mph Wind }\end{array}$ & $\begin{array}{c}\text { Dry Cond. } \\
30 \mathrm{mph} \\
\text { Wind }\end{array}$ & $\begin{array}{c}\text { SRS } \\
\text { Proportion } \\
(\%) \\
\end{array}$ \\
\hline 2 & Grass & 2.7 & 3.1 & 6.0 & 6.8 & 19 \\
\hline 3 & Tall Grass & 11.8 & 13.5 & 22.6 & 25.4 & $<1$ \\
\hline 5 & Young Shrubs & 2.0 & 4.9 & 3.3 & 9.8 & 6 \\
\hline 6 & Mature Shrubs $(<6 \mathrm{ft})$ & 3.9 & 4.6 & 7.6 & 9.5 & 1 \\
\hline 7 & Southern Rough & 3.8 & 4.6 & 7.2 & 8.3 & $<1$ \\
\hline 8 & Timber Litter & 0.6 & 0.7 & 0.7 & 1.0 & 21 \\
\hline 9 & Hardwood Litter & 1.3 & 1.3 & 2.0 & 2.3 & 41 \\
\hline 101 & Short Sparse Grass & 0.8 & 1.1 & 1.2 & 1.9 & 4 \\
\hline
\end{tabular}


Table 11. Mean flame length by surface fuel model for SWRA data with stand canopy data

\begin{tabular}{|c|l||c|c||c|c||c||}
\hline \multicolumn{2}{|c||}{ SWRA/Stand Data - 13 FBFM } & \multicolumn{5}{c||}{ Mean Flame Length (ft) } \\
\hline FBFM & \multicolumn{1}{|c||}{ Description } & $\begin{array}{c}\text { Moderate } \\
\text { Cond. 10 } \\
\text { mph Wind }\end{array}$ & $\begin{array}{c}\text { Dry Cond. } \\
\mathbf{1 0} \text { mph } \\
\text { Wind }\end{array}$ & $\begin{array}{c}\text { Moderate } \\
\text { Cond. 30 } \\
\text { mph Wind }\end{array}$ & $\begin{array}{c}\text { Dry Cond. } \\
\mathbf{3 0} \text { mph } \\
\text { Wind }\end{array}$ & $\begin{array}{c}\text { SRS } \\
\text { Proportion } \\
\text { (\%) }\end{array}$ \\
\hline $\mathbf{2}$ & Grass & 2.8 & 3.1 & 6.1 & 7.1 & 19 \\
\hline $\mathbf{3}$ & Tall Grass & 11.8 & 13.5 & 22.6 & 25.4 & $<1$ \\
\hline $\mathbf{5}$ & Young Shrubs & 2.0 & 4.9 & 3.3 & 9.8 & 6 \\
\hline $\mathbf{6}$ & Mature Shrubs (<6 ft) & 4.9 & 5.7 & 13.9 & 17.6 & 1 \\
\hline $\mathbf{7}$ & Southern Rough & 2.3 & 2.6 & 3.6 & 4.3 & $<1$ \\
\hline $\mathbf{8}$ & Timber Litter & 0.4 & 0.7 & 0.7 & 1.0 & 21 \\
\hline $\mathbf{9}$ & Hardwood Litter & 1.3 & 1.3 & 2.2 & 2.6 & 41 \\
\hline $\mathbf{1 0 1}$ & Short Sparse Grass & 1.0 & 1.4 & 1.3 & 2.0 & 4 \\
\hline
\end{tabular}

\section{Rate of Spread}

Trends in rate of spread for each fuel model are quite similar to trends for flame lengths; this phenomenon is mostly due to the fact that the grass and shrub surface fuel models are driving fire behavior and these fuel types tend to have longer flame lengths and faster rates of spread. Tables 12-15 depict mean rates of spread by fire behavior fuel model for LF40, LF13, SRLF, and SRSD data sources. Although the forested areas represent a substantial proportion of the area within each data source, the potential fire behavior within these forested areas have flame lengths less than 4 feet and rates of spread less than 6 chains $/ \mathrm{hr}$. The exception is surface fuel model 163 , described as moderate load of grass and shrubs with a timbered overstory that has an average flame length of 5.1 feet and mean rate of spread of 12.2 chains/hr with dry, windy conditions.

Table 12. Mean rate of spread by surface fuel model for LANDFIRE 40 FBFM

\begin{tabular}{|c|c|c|c|c|c|c|}
\hline \multicolumn{2}{|r|}{ LANDFIRE - 40 FBFM } & \multicolumn{5}{|c|}{ Mean Rate of Spread (chains/hr) } \\
\hline FBFM & Description & $\begin{array}{l}\text { Moderate } \\
\text { Cond. } 10 \\
\text { mph Wind }\end{array}$ & $\begin{array}{l}\text { Dry Cond. } \\
10 \mathrm{mph} \\
\text { Wind }\end{array}$ & $\begin{array}{c}\text { Moderate } \\
\text { Cond. } 30 \\
\text { mph Wind }\end{array}$ & $\begin{array}{c}\text { Dry Cond. } \\
30 \mathrm{mph} \\
\text { Wind }\end{array}$ & $\begin{array}{c}\text { SRS } \\
\text { Proportion } \\
(\%)\end{array}$ \\
\hline 101 & Short Sparse Grass & 2.5 & 4.1 & 6.8 & 12.6 & 4 \\
\hline 105 & Short Grass & 9.4 & 16.6 & 37.1 & 68.6 & 5 \\
\hline 108 & Tall Coarse Grass & 59.1 & 107.4 & 216.8 & 393.7 & $<1$ \\
\hline 147 & Tall Shrub, Shrub Litter & 5.0 & 6.3 & 15.0 & 21.1 & 13 \\
\hline 149 & Tall Shrub, Shrub Litter, Fine Fuels & 6.9 & 9.2 & 32.5 & 56.3 & $<1$ \\
\hline 161 & Timber-Grass-Shrub Low Load) & 0.0 & 0.3 & 0.3 & 1.2 & 2 \\
\hline 163 & Timber-Grass-Shrub (Moderate Load) & 2.7 & 3.8 & 8.8 & 12.2 & 17 \\
\hline 182 & Broadleaf Litter (Low Load) & 0.3 & 0.3 & 0.6 & 0.7 & 14 \\
\hline 186 & Broadleaf Litter (Moderate Load) & 0.9 & 1.2 & 2.8 & 3.4 & 39 \\
\hline
\end{tabular}


Table 13. Mean rate of spread by surface fuel model for LANDFIRE 13 FBFM

\begin{tabular}{|c|l||c|c||c|c||c||}
\hline \multicolumn{2}{|c||}{ LANDFIRE - 13 FBFM } & \multicolumn{5}{c||}{ Mean Rate of Spread (chains/hr) } \\
\hline FBFM & \multicolumn{1}{|c||}{ Description } & $\begin{array}{c}\text { Moderate } \\
\text { Cond. 10 } \\
\text { mph Wind }\end{array}$ & $\begin{array}{c}\text { Dry Cond. } \\
\mathbf{1 0} \text { mph } \\
\text { Wind }\end{array}$ & $\begin{array}{c}\text { Moderate } \\
\text { Cond. 30 } \\
\text { mph Wind }\end{array}$ & $\begin{array}{c}\text { Dry Cond. } \\
\mathbf{3 0} \text { mph } \\
\text { Wind }\end{array}$ & $\begin{array}{c}\text { SRS } \\
\text { Proportion } \\
\text { (\%) }\end{array}$ \\
\hline $\mathbf{2}$ & Grass & 3.1 & 7.3 & 33.0 & 39.9 & 5 \\
\hline $\mathbf{3}$ & Tall Grass & 0.0 & 109.8 & 378.8 & 447.4 & $<1$ \\
\hline $\mathbf{4}$ & Mature Shrubs $(>6 \mathrm{ft})$ & 5.7 & 16.0 & 56.4 & 79.7 & $<1$ \\
\hline $\mathbf{5}$ & Young Shrubs & 1.0 & 3.2 & 3.8 & 11.3 & 13 \\
\hline $\mathbf{7}$ & Southern Rough & 3.2 & 4.1 & 10.3 & 13.2 & 17 \\
\hline $\mathbf{8}$ & Timber Litter & 0.3 & 0.3 & 0.9 & 1.2 & 16 \\
\hline $\mathbf{9}$ & Hardwood Litter & 1.2 & 1.5 & 3.8 & 4.5 & 39 \\
\hline $\mathbf{1 0 1}$ & Short Sparse Grass & 2.5 & 4.1 & 6.8 & 12.6 & 4 \\
\hline
\end{tabular}

Table 14. Mean rate of spread by surface fuel model for SWRA data with LANDFIRE canopy data

\begin{tabular}{|c|l||c|c||c|c||c||}
\hline \multicolumn{2}{|c||}{ SWRA/LANDFIRE - 13 FBFM } & \multicolumn{5}{c||}{ Mean Rate of Spread (chains/hr) } \\
\hline \multicolumn{1}{|c|}{ FBFM } & \multicolumn{1}{|c||}{ Description } & $\begin{array}{c}\text { Moderate } \\
\text { Cond. 10 } \\
\text { mph Wind }\end{array}$ & $\begin{array}{c}\text { Dry Cond. } \\
\mathbf{1 0} \mathbf{~ m p h} \\
\text { Wind }\end{array}$ & $\begin{array}{c}\text { Moderate } \\
\text { Cond. 30 } \\
\text { mph Wind }\end{array}$ & $\begin{array}{c}\text { Dry Cond. } \\
\mathbf{3 0} \text { mph } \\
\text { Wind }\end{array}$ & $\begin{array}{c}\text { SRS } \\
\text { Proportion } \\
\text { (\%) }\end{array}$ \\
\hline $\mathbf{2}$ & Grass & 7.1 & 8.5 & 40.5 & 48.9 & 19 \\
\hline $\mathbf{3}$ & Tall Grass & 93.4 & 110.2 & 379.2 & 447.8 & $<1$ \\
\hline $\mathbf{5}$ & Young Shrubs & 5.4 & 16.5 & 19.1 & 73.0 & 6 \\
\hline $\mathbf{6}$ & Mature Shrubs (<6 ft) & 14.1 & 16.5 & 56.2 & 66.5 & 1 \\
\hline $\mathbf{7}$ & Southern Rough & 12.5 & 16.0 & 47.5 & 60.3 & $<1$ \\
\hline $\mathbf{8}$ & Timber Litter & 0.3 & 0.5 & 0.9 & 1.2 & 21 \\
\hline $\mathbf{9}$ & Hardwood Litter & 1.2 & 1.5 & 4.3 & 5.0 & 41 \\
\hline $\mathbf{1 0 1}$ & Short Sparse Grass & 3.7 & 6.0 & 7.0 & 13.3 & 4 \\
\hline
\end{tabular}

Table 15. Mean rate of spread by surface fuel model for SWRA data with canopy characteristics supplied by stand data

\begin{tabular}{|c|l||c|c||c|c||c||}
\hline \multicolumn{2}{|c||}{ SWRA/Stand Data - 13 FBFM } & \multicolumn{5}{c||}{ Mean Rate of Spread (chains/hr) } \\
\hline \multicolumn{1}{|c|}{ FBFM } & \multicolumn{1}{|c||}{ Description } & $\begin{array}{c}\text { Moderate } \\
\text { Cond. 10 } \\
\text { mph Wind }\end{array}$ & $\begin{array}{c}\text { Dry Cond. } \\
\mathbf{1 0} \text { mph } \\
\text { Wind }\end{array}$ & $\begin{array}{c}\text { Moderate } \\
\text { Cond. 30 } \\
\text { mph Wind }\end{array}$ & $\begin{array}{c}\text { Dry Cond. } \\
\mathbf{3 0} \text { mph } \\
\text { Wind }\end{array}$ & $\begin{array}{c}\text { SRS } \\
\text { Proportion } \\
\text { (\%) }\end{array}$ \\
\hline $\mathbf{2}$ & Grass & 6.8 & 8.2 & 38.8 & 47.1 & 19 \\
\hline $\mathbf{3}$ & Tall Grass & 93.4 & 110.2 & 379.2 & 447.8 & $<1$ \\
\hline $\mathbf{5}$ & Young Shrubs & 5.4 & 16.5 & 19.1 & 73.0 & 6 \\
\hline $\mathbf{6}$ & Mature Shrubs (<6 ft) & 15.4 & 18.2 & 61.8 & 74.6 & 1 \\
\hline $\mathbf{7}$ & Southern Rough & 3.0 & 3.9 & 9.8 & 12.2 & $<1$ \\
\hline $\mathbf{8}$ & Timber Litter & 0.3 & 0.3 & 1.0 & 1.3 & 21 \\
\hline $\mathbf{9}$ & Hardwood Litter & 1.3 & 1.6 & 4.5 & 5.8 & 41 \\
\hline $\mathbf{1 0 1}$ & Short Sparse Grass & 5.3 & 8.6 & 7.8 & 15.5 & 4 \\
\hline
\end{tabular}



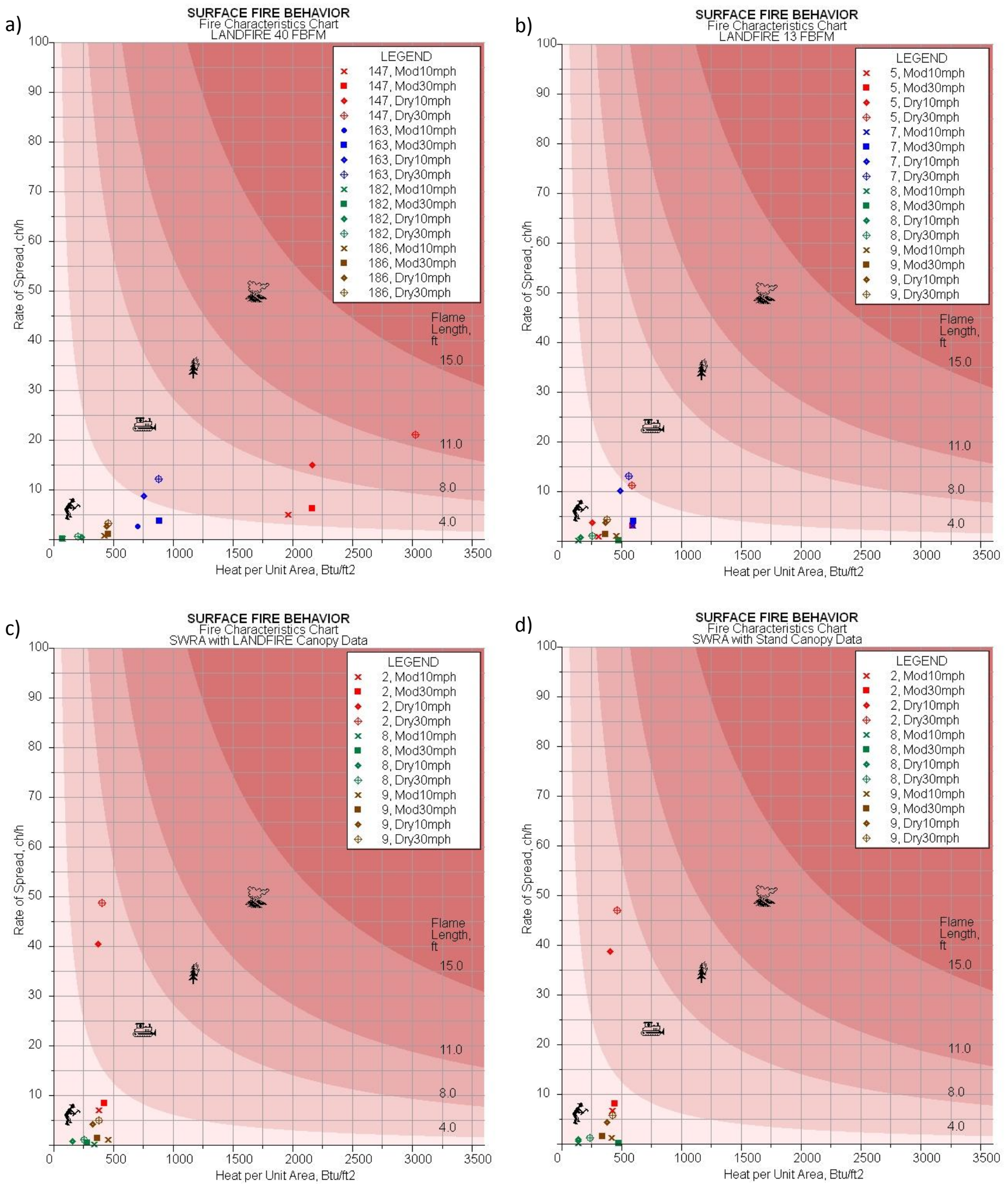

Figure 13. Fire characteristics charts for selected surface fuel models comprising greater than $10 \%$ of the SRS area for that data source for a) LF40, b) LF13, c) SRLF, and d) SRSD. Legend information includes FBFM, fuel moisture scenario (dry or moderate), and wind speed. 


\section{Discussion}

Differences in modeled fire behavior, data development, and data utility are summarized to assist in determining which data source may be most applicable for various land management activities and required analyses. Characterizing fire behavior under different fuel relationships and running simulations with various weather conditions and moisture scenarios provides insights for both natural ecological processes and management strategies for fire mitigation.

\section{Fire Behavior}

A comparison of flame length, rate of spread, crown fire activity, and burn probabilities modeled with FlamMap shows some similar patterns across the landscape from all data sources, but there are potentially important differences. All data sources showed an expected range of fire behavior with rate of spread varying greatest especially with higher wind speeds. Modeled fire behavior for the SRS indicates that even with dry and windy conditions, the majority of the area is expected to have low to moderate fire behavior with minimal torching and crown fire.

Burn probabilities, while different for each data set, indicate a pattern of highest burn probability to the southeast and a few areas in the north central. These results may be useful in guiding managers; however, further site, project, or incident specific analyses are required before making detailed planning and incident specific decisions. An additional exercise that may be helpful to the local unit is to evaluate modeled fire behavior adjacent to critical infrastructure.

Some of the differences in modeled fire behavior between the data sources can be attributed to the proportions of grass and shrub fuel types that are represented in each dataset and the dynamic herbaceous moisture content of the 40 FBFM from LANDFIRE. The live herbaceous load transfers to dead depending on the herbaceous moisture content in a dynamic fuel model (Scott and Burgan 2005). This allows the time of year to be factored in based on the level of curing of the herbaceous fuels. The variations in fire behavior demonstrate the differences in the underlying data and indicate the need to carefully evaluate data for accuracy. To discern some of the differences in modeled fire behavior, the fuel model compositions in each data source were examined for LANDFIRE and SWRA data. LF13 and LF40 had similar proportions of grass fuel models while SWRA had substantially higher proportion, which may explain why SWRA had the highest average rate of spread (Table 16).

Table 16. Fuel type composition for SWRA and LANDFIRE

\begin{tabular}{|c|c|c|c|c|}
\hline Data & \multicolumn{4}{|c|}{ Fuel Type } \\
\cline { 2 - 5 } Source & Grass & Shrub & Timber Understory & Broadleaf Litter \\
\hline LF40 & $5 \%$ & $13 \%$ & $19 \%$ & $53 \%$ \\
\hline LF13 & $5 \%$ & $30 \%$ & $16 \%$ & $39 \%$ \\
\hline SWRA & $19 \%$ & $7 \%$ & $21 \%$ & $41 \%$ \\
\hline
\end{tabular}

On average, modeled flame length and crown fire activity show little difference between the data sources. Average rate of spread shows greater variation between the data sources, yet it may be insignificant. However, the differences in maximum flame length and rate of spread may indicate important differences when assessed at the local scale and may be used to define 
areas where treatment may be desired to mitigate fire potential and fire effects. Additionally, data performance should be evaluated by comparing modeled fire behavior to observed fire behavior.

\section{Utility of Data}

Geospatial fire behavior systems have gained momentum in the last decade as they allow for landscape fire behavior analyses, support the strategic placement of fuels treatments, forecast burn probabilities, and are useful during wildfire incidents to deterministically and probabilistically project fire growth. To support geospatial fire behavior systems, several efforts have produced readily available data themes with state, regional, and national extents. Alternatively, local plot data can be used for analyses. The inherent usability of data for geospatial analyses varies. While many of the readily available data sources provide a valuable means for geospatial fire behavior analyses they do not provide sufficient detail for a stand or plot as they lack site-specific measured data.

The key to choosing the proper data source lies in asking and answering questions at the outset. Specific management objectives should be identified during this process. Important considerations when choosing data may include: data availability, data accuracy, project scale, site-specific inventory and monitoring, fire behavior analyses, values at risk analyses, and the ability to quantify fire effects (Table 17). If the objective is to provide spatial data at no direct cost to the user, either LANDFIRE or Southern Wildfire Risk Assessment may be valid choices. Both are easily available via the internet for the conterminous southeast U.S. and include a myriad of different vegetation and fuels data. Plot data, such as the FCCS fuel stratums or Forest Inventory Analysis (FIA), take more time to collect, require statistical analyses to assign attributes across a landscape, and require additional geographic information system (GIS) and custom fuel model expertise in order to develop data for geospatial fire spread analyses. LANDFIRE and SWRA offer seamless data available for the southeastern U.S. across all land ownerships. The FCCS data were imputed to the stand level within the study site area and therefore do not include adjacent lands.

Concerning data accuracy, scale is tantamount. Data accuracy can be very high for small projects where data can be collected at a relatively fine resolution. As the geographic scope of a project increases, it becomes more difficult to retain accuracy at a fine resolution. Usually data is limited, assumptions must be made to apply the data across a broad area, and data resolution becomes much coarser. The FCCS data collected at each plot are expected to be quite accurate; however, once the data are imputed to the stand it seems logical that accuracy would decrease. LANDFIRE and SWRA both use satellite imagery. LANDFIRE data were informed by available plot data and both data sources used local professional expertise to improve accuracy on a regional, but not local, scale. Accuracy is difficult to assess at a generalized broad scale and should best be evaluated by the local user. An important component to remember is that accuracy may be improved by calibrating data (Stratton 2009) which can heighten usability at the local scale. Because data accuracy can be improved at the local scale, this should not be the key driver to choosing the data source. 
Table 17. Comparison of data utility for FCCS, LANDFIRE, and SWRA data sources

\begin{tabular}{|c|c|c|c|}
\hline & FCCS & LANDFIRE & SWRA \\
\hline \multicolumn{4}{|l|}{ General } \\
\hline Data Source & Plot & Satellite & Satellite \\
\hline Resolution & Plot (imputed to stand) & $30 \mathrm{~m}$ & $30 \mathrm{~m}$ \\
\hline $\begin{array}{l}\text { Geographic Scale and } \\
\text { Extent }\end{array}$ & Savannah River Site & Complete national & Complete Southeast \\
\hline \multicolumn{4}{|l|}{ Inventory } \\
\hline Canopy Data & Plot (imputed to stand) & Complete & Canopy cover only \\
\hline $\begin{array}{l}\text { Comprehensive } \\
\text { Fuels Inventory }\end{array}$ & Yes & No & No \\
\hline $\begin{array}{l}\text { Relationship - Surface } \\
\text { Fuel Model and Canopy } \\
\text { Data }\end{array}$ & Dependent & Independent & Independent \\
\hline Surface Fuel Models & Custom & FBFM13, FBFM40 & FBFM13 \\
\hline \multicolumn{4}{|l|}{ Uses } \\
\hline Smoke Emissions & Complete & Limited & Very Limited \\
\hline Carbon Analysis & Complete & Limited & Very Limited \\
\hline Incident Management & Limited & Complete & Moderate \\
\hline Fuel Treatment Changes & $\begin{array}{l}\text { Surface fuels and } \\
\text { canopy data }\end{array}$ & Canopy data & Canopy cover \\
\hline $\begin{array}{l}\text { Quantify Prescribed Fire } \\
\text { Effects }\end{array}$ & Complete & Limited & Limited \\
\hline Quantify Wildfire Effects & Complete & Limited & Very Limited \\
\hline \multicolumn{4}{|l|}{ Data Collection } \\
\hline Field Verification & Data/subjective & Subjective & Subjective \\
\hline Costs & $\begin{array}{l}\text { High for plot collection } \\
\text { and conversion to } \\
\text { custom FBFM }\end{array}$ & Low & Low \\
\hline
\end{tabular}

The geographic scope of the project is important in determining data sources. Assessing fire behavior for a small project such as a prescribed fire, wildfire incident, or fuels treatment in a watershed requires the finest resolution and most accurate data available. Results of such analyses are often used to make tactical decisions that are important to achieve management objectives, particularly human safety. FCCS and FIA or other plot data provide the best accuracy and resolution. However, if a project encompasses a large geographic area, coarser resolution and lower accuracy may not only be acceptable but be required because it is the best data available. Analyses at this scale should be used primarily for strategic decisions. LANDFIRE and SWRA at $30 \mathrm{~m}$ resolution work well for larger scale analyses. However, as projects get larger, data may need to be aggregated to a coarser resolution due to computer processing capabilities. While fire behavior characteristics and a single fire spread prediction can be readily calculated at $30 \mathrm{~m}$ resolution, probabilistic models usually require a resolution of $90 \mathrm{~m}$ or greater for most landscapes. Aggregating the data introduces additional inaccuracies, making interpretation and application at a project-scale difficult. 
If the overriding objective is to provide a baseline inventory and allow for subsequent monitoring of all aspects of the fuels profile, a basis for effectiveness monitoring, or data for detailed fire effects analyses the Fuel Characteristic Classification System may be the best option. Plot data allow for detailed statistical analyses and provide the ability to track trends in vegetation and surface fuels over time or changes resulting from natural disturbances or management activities. This data may be useful to track certain types of habitat based on canopy characteristics or surface fuel loading.

If the objective is to perform spatial fire behavior modeling, LANDFIRE may be the best option although it could certainly be argued that SWRA and LANDFIRE data could be combined to satisfy this objective. At this point it may be suitable to consider the data accuracy and choose the most appropriate source for the analysis area. The FCCS data involved a prolonged process to yield spatial data from plot data; the necessary skills are often not locally available. Geospatial data are often used by incident management teams to provide consistent data during wildfires and the ability to perform spatial fire behavior analyses and calculate burn probabilities. The FCCS plot data would not allow for this use on incidents, but would still allow for point-based fire behavior analyses. While point-based analyses allow for assessment of site-specific changes in fire behavior before and after treatments, they may not be used to assess changes in fire spread across a landscape.

Analyzing threats from wildfire to values remains a viable concern in the southeastern U.S. The ability to prioritize areas that have the greatest risk can be helpful to local managers during a fire incident. Likewise, having the opportunity to complete multiple iterations representing potential treatments allows for informed decisions. The community risk rating data and wildfire risk index in SWRA provide the ability for local managers to analyze values potentially at risk from fire.

Quantifying fire effects can be very important to managers in order to determine whether prescribed fire and smoke management objectives were successfully met, to maintain a treatment history that can be consulted in comparable vegetation types, and to have an accurate record of the existing condition of vegetation all of which can be accomplished using plot data such as FCCS. In addition, this effort can include effects to other resources such as wildlife habitat, soils, and hydrology. Prescribed fire objectives often include goals for reducing surface fuel loadings; comparison of pre- versus post-fire loadings can be quantitatively summarized using plot data. Analyzing effects following wildfires may help determine if a particular fire was within the acceptable range of variability concerning management objectives, help determine reforestation needs to comply with applicable laws and policies, and track successional stages of vegetation. If a wildfire occurs in an area with plot data, remeasuring following the incident would be straightforward.

Data development and maintenance processes and data utility are paramount to choosing the data source most able to provide answers for management objectives. The formulation of management objectives that require answers remains the first critical question. The various data sources analyzed for this project are viable at different scales and are useful for an array of different analyses, but no one data source provides all the answers to all possible management objectives. 
An obvious benefit to remotely sensed data is the availability to all potential users; however current maintenance plans may be on a longer time scale than is sufficient to capture rapid changes. FCCS data is collected for a plot and is not spatial; a variety of steps are required in order to create spatial data. The resolution for FCCS remains at the plot but a diverse array of vegetation and fuels measurements are collected for each plot to create a baseline inventory. These plots can be remeasured at specific intervals to track trends over time. In addition, the plots can be resampled following treatment activities or disturbance providing the ability to discern effects to the individual fuel stratums from harvest, prescribed fire, unplanned ignitions, insect activity, or microsite disturbances such as windthrow. LANDFIRE and SWRA both lack the ability for plot-based inventory and monitoring of vegetation and fuels attributes.

LANDFIRE contains both the 40 FBFM (Scott and Burgan 2005) and the 13 FBFM (Anderson 1982) while SWRA relies on the 13 FBFM. FCCS is a unique system in that it requires custom fuel models in order to perform geospatial fire behavior analysis.

Validating the modeled fire behavior results by comparing the values to observed fire behavior is a critical next step. Actual fire observations may indicate how predicted fire behavior deviates from observed fire behavior. Observed patterns may allow formulation of general rules to apply to landscape data layers in order to increase reliability of modeled data. For example, more crown fire may be observed than has been predicted for specific weather conditions. Applying an adjustment factor to the layer that affects crown fire initiation (canopy base height) may adequately resolve the differences; thus establishing an adjustment factor that can be used to obtain more accurate predicted fire behavior. Observed fire behavior may also indicate patterns for changing FBFM in the data. With sufficient historic fire behavior and progression information, landscape data can be modified and calibrated prior to an incident or planning needs. However, if there is little available fire history, such modifications and calibration may need to occur during the incident or project implementation.

Calibrated data will improve the accuracy of geospatially modeled fire behavior and subsequent utility for planning and incident management. Modeled fire behavior that closely reflects observed behavior can be extremely important, particularly during planning, for evaluating potential fire effects to species that have tolerance thresholds. For example, underpredicting fire behavior may result in unintended longleaf pine mortality following a prescribed fire.

Accurate fire behavior modeling is especially important in incident management where decisions regarding human safety often hinge on predicted fire behavior, particularly flame length and rate of spread.

Calibration with actual fire behavior observed under modeled conditions is necessary to determine the reliability of the data; however, sufficient data can be difficult to acquire. When historic fire behavior can be compared with modeled fire behavior from calibrated data sets, statistical analyses can be applied to determine which data provide the best overall accuracy or may be most applicable for particular management situations. 


\section{Recommendations}

Based on the objectives identified at the outset of this project, the following conclusions can be reached:

1) Potential fire behavior varies by data source

2) Differences exist in fire behavior outputs based on fuel moisture values and wind speed

3) For the purpose of this analysis, extreme weather conditions were based on low fuel moisture values and $20 \mathrm{ft}$ winds of $30 \mathrm{mph}$. These conditions occurring concurrently had a strong influence on modeled fire behavior.

Local managers may have a feel for which data source may be most accurate and most appropriate based on management objectives. As the majority of fires are caused by humans, evaluating roadside fuels may be of value. Not only can roadside vegetation be managed to reduce potential fire behavior but also these locations can be used strategically during fire management operations.

Some of the prescribed fire objectives described in the Savannah River Natural Resource Management Plan relate directly to this study. Improving and maintaining certain types of habitat critical for wildlife often dovetails well with prescribed fire objectives. In addition, prescribed fire is an important tool used to enhance certain types of wildlife habitat and reduce fine woody fuels and litter to promote forage. In order to reduce hazardous fuels to modify fire behavior, the results presented in this report offer a critical insight to potential fire behavior under the various conditions modeled. Prescribed fire is often used following harvest activities to reduce residual slash and enhance site preparation. Fire is often a critical component in maintaining and promoting savannah communities. Although maintenance of open canopies can potentially promote fast rates of spread, there is often a low risk of torching or crown fire in these vegetation types with open stand structure.

In order to prioritize treatment areas, values can be intersected with modeled fire behavior. Values can include SRS infrastructure, certain types of habitat important for wildlife, vegetation communities of interest, or any other value deemed important by the local unit. For example, an area adjacent to sensitive SRS infrastructure would be an obvious candidate for treatment if flame lengths were predicted to be greater than 8 feet.

\section{Conclusion}

Multiple data sources are available for use with various fire behavior modeling systems. No one data source provides the utility or accuracy for a diverse fire management program. Selection of a data source to complete analyses for land management activities depends on the requisite scale of analysis and necessary resolution. Predicted fire behavior from the various data sources may have important differences and should be evaluated based on objectives. Most geospatial data for fire modeling has been developed to adapt to the requirements, limitations, and assumptions of existing fire behavior modeling systems. SWRA and LANDFIRE data provide spatial data that can be used for fire growth modeling; however, the accuracy may limit the utility for an individual project. FCCS is a relatively new system that attempts to overcome 
some previously imposed limits; however, it currently does not provide geospatial data to analyze potential fire progression or analyze burn probabilities without imputing plot data to the stand. Areas subject to frequent disturbance or rapid succession will require regular evaluation and modification to ensure data reflects field conditions. Some data sources have regular maintenance schedules while others may require manual updates from the user.

While all data sources have utility, each fits a different niche and determination of the best fit depends on the particular management objectives in question. The most critical step in choosing the best data and appropriate analyses is clearly defining the metrics that will determine if the management objectives are achievable or have been achieved. On-going research is being conducted to better understand various aspects of fire behavior, particularly crown fire. As this research becomes integrated, more detailed data may provide better analyses and broader utility for multiple objectives.

\section{Acknowledgements}

The authors would like to thank the reviewers for their thoughtful comments on improving this manuscript. Funding for data collection was provided by the United States Department of Energy. The USDA Forest Service, Rocky Mountain Research Station and Fire Modeling Institute, Pacific Northwest Research Station, and Southern Research Station provided instrumental funding to prepare and analyze data and prepare this manuscript.

\section{References}

Anderson, H.E. 1982. Aids to determining fuel models for estimating fire behavior. United States Department of Agriculture, Forest Service General Technical Report INT-GTR-122, Ogden, UT.

Andreu, A.G., Shea D., Parresol, B.R., Ottmar, R.D., (in press). Evaluating fuel complexes for fire hazard mitigation in the southeastern United States. Forest Ecology and Management. (Available online http://www.sciencedirect.com/science/article/pii/S0378112711004026)

Bradshaw L.S., Tirmenstein D.A., (in preparation). FireFamilyPlus user's guide, version 4.0. United States Department of Agriculture, Forest Service General Technical Report.

Buckley D., Carlton, D., Krieter, D., Sabourin K. 2006. Southern wildfire risk assessment project final report. Sanborn Total Geospatial Solutions, Colorado Springs, CO.

Finney, M.A. 2006. An overview of FlamMap fire modeling capabilities. In: Andrews, P.L., Butler, B.W., (Comps.), Fuels Management-How to Measure Success: Conference Proceedings. United States Department of Agriculture, Forest Service General Proceedings RMRS-P-41, Fort Collins, CO.

Hollingsworth, L.T., Kurth, L.L. 2010. Detailed methodology of geospatial fire behavior analyses for the Savannah River Site. Unpublished report on file at Rocky Mountain Research Station, Missoula Fire Sciences Laboratory, Missoula, MT. 
Ottmar, R.D., Sandberg, D.V., Riccardi, C.L., Prichard, S.J., 2007. An overview of the Fuel Characteristic Classification System - Quantifying, classifying, and creating fuelbeds for resource planning. Canadian Journal of Forest Research 37, 2383-2393.

Ottmar, R.D., Prichard, S.J., (in press). Fuel treatment effectiveness in forests of the upper Atlantic Coastal Plain - An evaluation at two spatial scales. Forest Ecology and Management. (Available online http://www.sciencedirect.com/science/article/pii/S0378112711005998)

Parresol, B.R., Scott, J.H., Andreu, A., Prichard, S., Kurth, L., (in preparation). Developing custom fire behavior fuel models from ecologically complex fuel structures for upper Atlantic coastal plain forests. Forest Ecology and Management.

Reeves, M.C., Ryan, K.C., Rollins, M.G., Thompson, T.G. 2009. Spatial fuel data products of the LANDFIRE project. International Journal of Wildland Fire 18, 250-267.

Rollins, M.G. 2009. LANDFIRE: a nationally consistent vegetation, wildland fire, and fuel assessment. International Journal of Wildland Fire 18, 235-249.

Sandberg, D.V., Riccardi, C.L., Schaaf, M.D. 2007. Fire potential rating for wildland fuelbeds using the Fuel Characteristic Classification System. Canadian Journal of Forest Research 37, 2456-2463.

Scott, J.H., Burgan, R.E. 2005. Standard fire behavior fuel models: A comprehensive set for use with Rothermel's fire spread model. United States Department of Agriculture, Forest Service General Technical Report RMRS-GTR-153, Fort Collins, CO.

Stratton, R.D. 2009. LANDFIRE fuels data acquisition, critique, modification, maintenance, and model calibration. United States Department of Agriculture, Forest Service General Technical Report RMRS-GTR-220, Fort Collins, CO. 


\section{APPENDIX A. Acronyms and Abbreviations}

\begin{tabular}{l|l} 
ac & acres \\
BP & burn probability \\
CFA & crown fire activity \\
DOE & Department of Energy \\
FBFM & fire behavior fuel models \\
FCCS & Fuel Characteristic Classification System \\
FIA & Forest Inventory Analysis \\
FL & flame length \\
GIS & geographic information system \\
hr & hour \\
LCP & landscape file used in FlamMap \\
LF13 & LANDFIRE data with 13 fire behavior fuel models \\
LF40 & LANDFIRE data with 40 fire behavior fuel models \\
LFDAT & LANDFIRE Data Access Tool \\
m & meters \\
mph & miles per hour \\
ROS & rate of spread \\
SRLF & Southern Wildfire Risk Assessment data with LANDFIRE canopy data \\
SRS & Savannah River Site \\
SRSD & Southern Wildfire Risk Assessment data with stand canopy data \\
SWRA & Southern Wildfire Risk Assessment \\
&
\end{tabular}




\section{APPENDIX B. Glossary}

aspect - the cardinal direction in which a slope faces

burn probability - expresses the fraction of fires encountered at each node ranging between 0.0 to 1.0, in FlamMap this is an output from the minimum travel time model. Large fires yield higher probabilities than small fires as a larger proportion of landscape burns.

canopy base height - the height to the bottom of the live crown including understory ladder fuels canopy bulk density - mass of available canopy fuel per unit canopy volume of a stand chains/hour - chains per hour $(1$ chain $=66 \mathrm{ft})$

crown fire - a fire that spreads in the canopy of trees or shrubs more or less independent of a surface fire.

fine woody debris - dead wood less than 3 inches in diameter or 1-, 10-, and 100-hr timelag fuels

flame length - within the flaming front, the length of the flame of a spreading surface fire; a function of fire intensity that influences the effect on vegetation.

foliar moisture - moisture content of overstory foliage; one of the attributes used to determine transition from surface to crown fire; $100 \%$ refers to mature foliage with new growth complete.

fuel model - a cohesive set of parameters that define the necessary inputs to the fire spread model.

ladder fuels - fuels that provide vertical continuity between surface and canopy fuels; an example would be conifer seedlings and saplings

live fuel moisture - herbaceous and live woody fuels; $100 \%$ refers to mature foliage with new growth complete.

rate of spread - the rate of forward spread of fire as measured in chains/hour, in FlamMap the default option expresses the maximum rate of spread for each pixel.

slope - the ratio between the amount of vertical rise of a slope and horizontal distance as expressed in a percent

surface fire - a fire that burns close to the ground surface including dead branches, leaves, and low vegetation.

torching - a fire that burns a single tree or group of trees, also known as passive crown fire. twenty-foot winds - wind speed and direction at 20 feet above the height of the top of the vegetation 
APPENDIX C. FlamMap theme by data source

\begin{tabular}{|c|c|c|c|}
\hline $\begin{array}{l}\text { FlamMap } \\
\text { Theme }\end{array}$ & Custom FCCS & LANDFIRE & Southern Wildfire Risk \\
\hline ASPECT & LANDFIRE & $\begin{array}{l}\text { Range }=-1-359^{\circ} \\
-1 \text { values (flat ground) retained }\end{array}$ & $0^{\circ}, 90^{\circ}, 180^{\circ}, 270^{\circ}$ \\
\hline SLOPE & LANDFIRE & Range $=0-28 \%$ & Range $=0-54 \%$ \\
\hline ELEVATION & LANDFIRE & Range $=19-150 \mathrm{~m}$ & Range $=17-151 \mathrm{~m}$ \\
\hline $\begin{array}{l}\text { CANOPY } \\
\text { BULK } \\
\text { DENSITY }\end{array}$ & $\begin{array}{l}\text { Local stand data, } \\
\text { Range }=0-70 \\
\text { Units }=\mathrm{kg} / \mathrm{m}^{3} * 100\end{array}$ & $\begin{array}{l}\text { Range }=0-24 \\
\text { Units }=\mathrm{kg} / \mathrm{m}^{3} * 100\end{array}$ & $\begin{array}{l}\text { LANDFIRE and local stand } \\
\text { data both used. }\end{array}$ \\
\hline $\begin{array}{l}\text { CANOPY } \\
\text { BASE } \\
\text { HEIGHT }\end{array}$ & $\begin{array}{l}\text { Local stand data, } \\
\text { Range }=0-177 \\
\text { Units }=m * 10\end{array}$ & $\begin{array}{l}\text { Range }=0-100 \\
\text { Units }=m * 10\end{array}$ & $\begin{array}{l}\text { LANDFIRE and local stand } \\
\text { data both used. }\end{array}$ \\
\hline $\begin{array}{l}\text { CANOPY } \\
\text { COVER }\end{array}$ & $\begin{array}{l}\text { Local stand data, } \\
\text { Range }=0-97 \%\end{array}$ & Range $=0-95 \%$ & $0 \%, 10 \%, 35 \%, 65 \%$ \\
\hline $\begin{array}{l}\text { STAND } \\
\text { HEIGHT }\end{array}$ & $\begin{array}{l}\text { Local stand data, } \\
\text { Range }=0-375 \\
\text { Units }=m * 10\end{array}$ & $\begin{array}{l}\text { Range }=0-375 \\
\text { Units }=m * 10\end{array}$ & $\begin{array}{l}\text { LANDFIRE and local stand } \\
\text { data both used. }\end{array}$ \\
\hline $\begin{array}{l}\text { FUEL } \\
\text { MODEL }\end{array}$ & $\begin{array}{l}\text { Custom fuel models developed } \\
\text { from FCCS fuelbeds. Augmented } \\
\text { SRS area with LANDFIRE data to } \\
\text { fill in the landscape (used } \\
\text { FBFM } 40^{1} \text { ). Have } 95 \text { records = } 0 \\
\text { in the SRS (there were some } \\
\text { missing values in } 2 \text { stands). } \\
\text { Refined with local data to better } \\
\text { represent lakes and streams (FM } \\
98 \text { ) and 2-track roads (FM 101). }\end{array}$ & $\begin{array}{l}\text { Used FBFM } 13^{2} \text { and FBFM } 40^{1} \text {. } \\
\text { Both were refined with local data to } \\
\text { better represent lakes and streams } \\
\text { (FM 98). The FBFM } 13 \text { were also } \\
\text { updated to better represent } \\
\text { unburnable fuel models (FM 91, 93, } \\
\text { 99) and 2-track roads (FM 101). }\end{array}$ & $\begin{array}{l}\text { FBFM } 13^{2} \text {. The original fuel } \\
\text { model classification was } \\
\text { modified to better represent } \\
\text { unburnable fuel models (FM } \\
91,96,97,98,99 \text { ) and } 2 \text {-track } \\
\text { roads (FM 101) based on local } \\
\text { data. }\end{array}$ \\
\hline $\begin{array}{l}\text { Number of } \\
\text { FlamMap } \\
\text { Runs }\end{array}$ & $\begin{array}{l}8 \text { Runs (4 using FLI custom fuel } \\
\text { model file, } 4 \text { using ROS custom } \\
\text { fuel model file) } \\
\frac{\text { Moderate Conditions }}{\text { wind, } 30 \text { mph wind }}-10 \mathrm{mph} \\
\frac{\text { Dry Conditions }}{\mathrm{mph} \text { wind }}-10 \mathrm{mph} \text { wind, } 30\end{array}$ & $\begin{array}{l}8 \text { Runs ( } 4 \text { for FBFM } 13^{2} \text { and } 4 \text { for } \\
\text { FBFM40 }{ }^{1} \text { ) } \\
\frac{\text { Moderate Conditions }}{\text { wind, } 30 \mathrm{mph} \text { wind }} 10 \mathrm{mph} \\
\frac{\text { Dry Conditions }}{\mathrm{mph} \text { wind }}-10 \mathrm{mph} \text { wind, } 30\end{array}$ & $\begin{array}{l}8 \text { Runs (4 for } \\
\text { SWRA/LANDFIRE combo and } \\
4 \text { for SWRA/stand data } \\
\text { combo) } \\
\text { Moderate Conditions }-10 \mathrm{mph} \\
\text { wind, } 30 \text { mph wind } \\
\frac{\text { Dry Conditions }-10 \mathrm{mph} \text { wind, }}{30 \mathrm{mph} \text { wind }}\end{array}$ \\
\hline
\end{tabular}

${ }^{1} 40$ Fire Behavior Fuel Models (FBFM) as described by Scott and Burgan (2005)

${ }^{2} 13$ Fire Behavior Fuel Models (FBFM) as described by Anderson (1983) 


\section{APPENDIX D. Limitations, Assumptions, and Scientific Accuracy}

\section{Limitations}

All modeling simulations have limitations and it is critical to consider how these limitations may affect simulation outputs and management considerations. The fuel moisture values were not conditioned as the terrain is relatively flat. Using custom fire behavior fuel models can be challenging as the stands were grouped based on similar fire behavior outputs calculated within FCCS. As stands change in the future due to disturbance, treatments, and succession it may be problematic to update the custom FBFM data without repeating the entire process.

The National version of LANDFIRE was used as that was the version available for the southeast when analyses were completed; however, Refresh 2008 version data became available in early 2011 for the southeast. This version updated LANDFIRE layers to incorporate natural disturbances and activities that occurred through 2008 and resolve discrepancies detected from the initial mapping effort.

\section{Assumptions}

The custom fire behavior fuel models are assumed to accurately represent modeled fire behavior.

The surface fire spread model as developed by Rothermel (1972) uses fire behavior fuel models (FBFM) to compartmentalize the physical and chemical fuel inputs necessary for the model. Additional models have incorporated substantive changes including crown fire initiation (Van Wagner 1977) and crown fire spread (Rothermel 1991) that have been combined in some of the fire behavior systems. The assumptions underlying the surface fire spread model assume homogeneity in what is naturally a dynamic system. It is therefore crucial to combine model outputs with professional judgment to ensure the results are valid and believable (Williams and Rothermel 1992). The following assumptions regarding the surface fire spread model and FlamMap are essential to consider.

\section{Surface Fire Spread Model}

1. The fire is free-burning. Hence, suppression actions are not accounted for and the ignition origin is not influencing the fire.

2. Fine fuels less than 1 inch in diameter are more important to the fire's spread than larger fuels.

3. Fire is predicted at the flaming front (direction of maximum spread). The surface area to volume ratio of the fuels determines the residence time of the flaming front.

4. Fuels are continuous and homogeneous.

5. The basic spread model is for a surface fire burning within surface fuels. Smoldering and long-range spotting are not considered as they are outside 
the scope of the surface fire spread model. The fire spread model can predict torching, crowning, or spotting if combined with other models.

6. Weather is uniform and consistent.

7. Topography is uniform.

8. The model has been designed for peak fire season. July and August are the peak fire months for the HNF as the majority of acres have burned in these two months.

9. The fire perimeter is based on a smooth ellipse.

\section{FlamMap}

1. Fire behavior is independent of neighboring cells.

2. Travel time across a cell is not influenced by neighboring cells with Minimum Travel Time model.

3. FlamMap v. 3.0 does not include spotting from firebrands.

4. Wind speed, wind direction, and fuel moistures are constant for the simulation period.

5. Fire spread due to rolling debris or falling snags are not included.

\section{Scientific Accuracy}

Modeling has often been described as both an art and a science. While some level of error or uncertainty exists, models are often used for providing insight and understanding regarding complex and intricate phenomenon. It is difficult to predict fire behavior due to the interaction of numerous dynamic components, including weather (windspeed and direction, temperature, relative humidity), fuel moisture, topography, and the size of the fire front moving through. 


\section{APPENDIX E. Data Products Provided}

In addition to this report, one additional report and numerous data products were produced during the course of this project and provided on an external hard drive to the Forest ServiceSavannah River.

\section{Reports}

Hollingsworth, L.T. and L.L. Kurth. 2011. Detailed methodology of geospatial fire behavior analyses for the Savannah River Site. Missoula, MT: Rocky Mountain Research Station.

\section{FlamMap Data and Results}

FCCS (Fuel Characteristic Classification System)

- Landscape file (LCP)

- Fuel moisture (FMS) files for moderate and dry conditions

- Custom fuels files (FMD)

- ROS file - ROS, burn probability

- FLI file - flame length, crown fire activity

- Archived FlamMap project (FZA)

- 16 output ascii files

- 16 output rasters

- Numerous AMLs to automate conversion and assignment of GIS data

LANDFIRE - 13 fire behavior fuel models

- Landscape file (LCP)

- Fuel moisture (FMS) files for moderate and dry conditions

- Archived FlamMap project (FZA)

- 16 output ascii files

- 16 output rasters + 7 additional rasters specific to FBFM

- Numerous AMLs to automate conversion and assignment of GIS data

LANDFIRE - 40 fire behavior fuel models

- Landscape file (LCP)

- Fuel moisture (FMS) files for moderate and dry conditions

- Archived FlamMap project (FZA)

- 16 output ascii files

- 16 output rasters + 7 additional rasters specific to FBFM

- Numerous AMLs to automate conversion and assignment of GIS data

Southern Wildfire Risk Assessment/LANDFIRE canopy data

- Landscape file (LCP)

- Fuel moisture (FMS) files for moderate and dry conditions

- Archived FlamMap project (FZA)

- 16 output ascii files 
- 16 output rasters + 7 additional rasters specific to FBFM

- Numerous AMLs to automate conversion and assignment of GIS data

Southern Wildfire Risk Assessment/stand data canopy data

- Landscape file (LCP)

- Fuel moisture (FMS) files for moderate and dry conditions

- Archived FlamMap project (FZA)

- 16 output ascii files

- 16 output rasters + 7 additional rasters specific to FBFM

- Numerous AMLs to automate conversion and assignment of GIS data

88 DBF files (can be viewed in Excel)

16 Excel spreadsheet files

\section{GIS Data}

FCCS (Fuel Characteristic Classification System)

- 8 rasters (FlamMap inputs)

LANDFIRE - 13 fire behavior fuel models

- 8 rasters (FlamMap inputs)

LANDFIRE - 40 fire behavior fuel models

- 8 rasters (FlamMap inputs)

Southern Wildfire Risk Assessment/LANDFIRE canopy data

- 8 rasters (FlamMap inputs)

Southern Wildfire Risk Assessment/stand data canopy data

- 8 rasters (FlamMap inputs)

Non-burnable FBFM

- 5 rasters (masks) for paved roads, 2-track roads, urban/developed areas, lakes, and streams

\section{Forest Ecology and Management Journal}

Andreu, A.G., D. Shea, B.R. Parresol, R.D. Ottmar. In press. Evaluating fuel complexes for fire hazard mitigation planning in the southeastern United States. Forest Ecology and Management.

Hollingsworth, L.T., L.L. Kurth, B.R. Parresol, R.D. Ottmar, S.J. Prichard. In press. A comparison of geospatially modeled fire behavior and fire management utility of three data sources in the southeastern United States. Forest Ecology and Management.

Ottmar, R.D. and S.J. Prichard. In press. Fuel treatment effectiveness in forests of the upper Atlantic Coastal Plain - An evaluation at two spatial scales. Forest Ecology and Management. 
Ottmar, R.D., J.I. Blake, W.T. Crolly. In press. Using fine-scale fuel measurements to assess wildland fuels, potential fire behavior and hazard mitigation treatments in the southeastern USA. Forest Ecology and Management.

Interim Papers and Presentations - includes miscellaneous preliminary reports 